\title{
A Mamlūk-Andalusi Holograph Manuscript of the Former Marīnid Chancellor Muḥammad Ibn Ḥizb Allāh al-Wādī Āshī (d. $788 \mathrm{H} / 1386 \mathrm{CE})$
}

A large corpus of manuscripts created by Andalusis living in Mamlūk lands have survived, tracing the new lives that they built far away from their birthplaces. These documents illustrate interests, scholarly and professional activities, and, in those cases where a scholar had not attracted the attention of Mamlūk authors, also provide exceptional sources for reconstructing their fate, as well their own expression, and perception, of themselves. It is clear that the Andalusis used these manuscripts for private study, for the education of their children, as a means of transmission of their own knowledge, as well as a source of income. In some cases, the manuscripts enable readers to clearly establish the context in which they were created. How a specific volume was used over time and how its meaning changed through the generations can also often be ascertained. Thus, these manuscripts allow one to look beyond the factual depiction of the presence of the Maghrib in the Mashriq, as it was shaped by Mamlūk authors, and offer a unique opportunity to assess their author's identity and cultural acts of expression. ${ }^{1}$ Biographical sketches in Western sources often end at the moment of their departure from the Maghrib, while Eastern ones start with their arrival in the East.

1 In this paper the words Maghrib/Maghribi and West and Western are used to denote the Islamic West as a whole. For the specific regions terms such as al-Andalus, Granada, Fez, and Tunis or their dynastic equivalents are used. The terms Mashriq and the East are used to denote everything eastwards of Ḥafșid Tripolis.

Note: The work for this paper was carried out during my research stay at the Annemarie Schimmel Kolleg in Bonn. I would like to thank Stephan Conermann and Bethany Walker for giving me the opportunity to develop this line of research. The first version of this paper was presented in Bonn in September 2018 and a second version at the Madrid workshop, "The Maghrib in the Mashriq" in December 2018. I am grateful to Maribel Fierro and Mayte Penelas for inviting me. To my colleague, Pavel Sládek, I am grateful for his support. Anna Gilliland's linguistic revision made the publication of this paper possible. Without her effort, Ibn Ḥizb Allāh would have stayed buried in history. Research for this article was supported in part by the project La Granada nazarí en el siglo XV: microhistoria de una entidad islámica en Occidente (FFI2016-79252-P AEI/FEDER,UE), co-directed by Ana M. 므 Carballeira and Amalia Zomeño. 
Their previously acquired identity and skills clearly helped these scholars to adapt to this new Mashriq life, and this 'dual reality' is worthy of exploration.

In such a context, and within the framework of this volume, this paper aims to analyze three holograph ijāzas (permission for transmission), with a fragment of a previously unknown Rị̣la, given by Muhammad Ibn Hizb Allāh al-Ṭā'ì alWādī Āshī (712-788 H/1312-3-1386 CE), a former Marīnid chancellor, to Burhān al-Dīn Ibrāhīm Sibṭ Ibn al-'Ajamī (753-841 H/1352-1438 CE), a muhaddith (scholar of hadith) from Aleppo. These ijāzas were given in Damascus in $784 \mathrm{H} /$ $1382 \mathrm{CE}$ and provide evidence of how an Andalusi scholar living in Mamlūk lands created and passed on an ego-document to a local scholar, as well as how this document transformed in meaning over the next 55 years of Sibt Ibn al- 'Ajamì's life. ${ }^{2}$ This change in meaning of the manuscript suggests that the understanding and reception of an ego-document depends on the "symbolic universe" current in the society at that particular moment in time, and how it can be enhanced by the presence of other scholars, in this case from the West. ${ }^{3}$ Specifically, it points to the personal contacts Andalusis made between themselves in Mamlūk territory and the use of a certain Mamlūk-Andalusi manuscript among Mamlūk scholars.

Available evidence permits an analysis of the use to which this particular manuscript was put on various occasions, from its creation until the death of its owner, Sibt Ibn al-'Ajamī. It forms part of his extensive Thabat (a scholar's study diary) that accompanied him his whole life. ${ }^{4}$ The ijāzas were written in either the handwriting of Ibn Hiizb Allāh or that of his and Sibṭ Ibn al-'Ajamī's friend, Abū al-Ḥasan/Abū 'Abd Allāh Ibn Maymūn al-Balawī, who was also Andalusi. They are Ibn Hiizb Allāh's expressions of his personal cultural identity and are part poetry and part travelogue. In composition they differ from the rest of Sibt Ibn al'Ajamì's Thabat, rather, reflecting the form similar to other ijāzas given in al-Andalus at that time. To consider them as ego-documents, and not just another sample of his wider works, we must look "at not what is represented but how this representation has been interpreted and perceived”. ${ }^{5}$ As Ibn Hizb Allāh's texts

2 On "ego-documents" see Frenkel 2018, 29-31; on holograph manuscripts see Bauden/Franssen 2019, 1-37.

3 Confino 1997, 1391.

4 Kristina Richardson translates the word thabat as a scholarly autobiography (Richardson 2016, 31). Although thabat represents a type of autobiographical expression, it is not a coherent narrative of its author's life. Thus, I opted for the term a 'scholar's study diary' since that is more related to one's everyday activities than to the expression of self. Likewise, Reynolds et al. translate thabat as a catalog of teachers, which clearly does not apply to the Thabat of Sibt Ibn al'Ajamī. See Reynolds 2001, 42.

5 Confino 1997, 1392. 
can only be understood through intermediaries who interacted with them, it is their relationship to Sibt Ibn al-'Ajamī's Thabat, its readers and users, which is crucial for the confirmation of Ibn Hiizb Allāh's presence in Mamlūk territory after he met Sibț Ibn al-'Ajamī.

\section{The Thabat of Sibt Ibn al-'Ajamī and his History with the Andalusis}

The manuscript of Sibt Ibn al-'Ajamī's Thabat is now held in the Jafet Library of the American University of Beirut. ${ }^{6}$ It is part of a large, dispersed, corpus of surviving manuscripts produced, owned, or used by Sibț Ibn al-'Ajamī throughout his life. Although one of many thabats from Aleppo, it is certainly the most famous. It comprises 722 pages, of which 721 are paginated, and 361 folios. However, it appears to be incomplete at the end. ${ }^{7}$ It spans the period from $776 \mathrm{H} /$ $1375 \mathrm{CE}$ to $810 \mathrm{H} / 1408 \mathrm{CE}$ and is composed of samā' $\bar{a} t$ and qira' $\bar{a} t$ (listening and reading certificates), ijāzas, excerpts of poetry, historical records, an autobiographical sketch of Sibt Ibn al-'Ajamī, travel and study notes, the birth dates of his sons, and other information he considered worthy of recording. It was Sibt Ibn al-'Ajamì's constant companion on the travels he undertook in the pursuit of knowledge, journeys that took him from Aleppo to Damascus, Cairo, Alexandria and other Mamlūk cities. In addition, Sibṭ Ibn al-'Ajamī was assiduous in collecting autographs of his teachers. Ibn Hiizb Allāh's text fits into this category, although his is only one of three Andalusi/Maghribi scholars collected by Sibț Ibn al-'Ajamī.

It was Sibț Ibn al-'Ajamī's previous experience and interaction with Andalusis that ultimately led to his encounter with Ibn Ḥizb Allāh. During his early years in Aleppo, he studied with two close friends, Abū Ja far Aḥmad Ibn Mālik alRu'aynī (708 or 709-779 H/1308-10-1378 CE) and Abū 'Abd Allāh Muhammad Ibn Jābir al-Hawwārī (698-780 H/1298-9-1378 CE). ${ }^{8}$ A part of what looks like a

6 For Sibț Ibn al-'Ajamī see Wādi` al-Thabītī 1418/1997-8.

7 Ibn Ḥajar’s biography of a kātib of Granada, Sahl b. Mālik (d. after 821 H/1418-9 CE), suggests that Sibt Ibn al-'Ajamī continued to collect similar material well after the year 810 H/1407 CE. See Ibn H̦ajar, al-Majma' (1994), 3: 119.

8 Sibț Ibn al-'Ajamī also noted their dates of birth and death (Sibț Ibn al-'Ajamī, "Thabat”, AUB MS:297.124:S941tA, 184). Both of them are mentioned as his teachers but Ibn Mālik is more prevalent. Interestingly, they wrote together another currently lost Rihla produced by Mamlūk-Andalusis. Sibṭ Ibn al-'Ajamī’s son Abū Dharr mentions that it was a one-volume work. See Sibṭ Ibn 
barnāmaj of Ibn Mālik al-Ru'aynī was even copied into his Thabat. ${ }^{9}$ We can but speculate if their influence played any role in his future interest in meeting Ibn Ḥizb Allāh. However, we do know that another Andalusi, Ibn Maymūn al-Balawī (ca. 750-792 H/ca. 1350-1389-90 CE) did play a major role in his life, and also in his Thabat.

In all likelihood Sibṭ Ibn al-'Ajamī and Ibn Maymūn al-Balawī were introduced sometime in Ramaḍān 776 (February 1375), when Ibn Maymūn al-Balawī came to Aleppo to read hadith in the madrasa al-Sharafiyya. ${ }^{10}$ In $780 \mathrm{H} / 1378 \mathrm{CE}$ they met again in Jabal Qāsiyūn next to Damascus. ${ }^{11}$ From Muharram to Rabī' alThānī 780 (Apr.-Aug. 1378), they studied together in Damascus, and later in Cairo in 780-782 H/1379-80 CE. ${ }^{12}$ Ibn Maymūn al-Balawī copied the samā' $\bar{a} t$ and qirā'a $\bar{t}$ certificates from Sibt Ibn al-'Ajamī's Thabat and penned some of the certificates in his own handwriting, including two ijāzas. ${ }^{13}$ Likewise, Sibt Ibn al-'Ajamī copied some of the thoughts of Ibn Maymūn al-Balawi ${ }^{14}$ After a break of several years, their paths crossed again, in Damascus in $784 \mathrm{H} / 1382 \mathrm{CE}$ during an encounter with Ibn Hiizb Allāh. In 785 H/1383 CE, in Cairo, Sibṭ Ibn al-'Ajamì took some classes with Ibn Maymūn al-Balawī, and he finally included him on the list of his teachers at the beginning of his Thabat. ${ }^{15}$ They parted ways in 785 H/1383 CE, when Ibn Maymūn al-Balawī left for Mecca, and never saw each other again. ${ }^{16}$

There is no other scholar from this period with whom Sibt Ibn al-'Ajamī shared his Thabat so extensively, nor any other with whom he interacted so

al-'Ajamī, Kunūz al-dhahab (1996), 1: 473. For Ibn Mālik al-Ru'aynī, see Navarro i Ortiz/Lirola Delgado 2012; for Ibn Jābir al-Hawwārī, Lirola Delgado/Ferrando 2009.

9 Sibt Ibn al-'Ajamī, "Thabat”, AUB MS:297.124:S941tA, 557-560. It consists of a long list of Mālikī works with isnāds copied before Sibṭ Ibn al-'Ajamī’s second trip to Cairo from Ibn Mālik’s own handwritten notes.

10 Ibn Maymūn al-Balawī, "Ijāza”, Dār al-Kutub MS majmū'a 135, fols. 98v and 103v. There are two manuscripts that Ibn Maymūn al-Balawī created during his journey to Aleppo. One is an excerpt of al-Būnī's work (Berlin MS Mq 123, fols. 76r-81v) and the other is his 20 page long holograph ijāza to transmit Qur'ānic readings on his authority (Ibn Maymūn al-Balawī, "Ijāza”, Dār al-Kutub MS majmū'a 135, fols. 94r-103v). The latter text I prepared for an edition with an introductory study.

11 Sibț Ibn al-'Ajamī, "Thabat”, AUB MS:297.124:S941tA, 189.

12 Sibț Ibn al-'Ajamī, “Thabat”, AUB MS:297.124:S941tA, 186, 206, 226, 246, 266, 286, 324, 404, 470.

13 See especially Sibț Ibn al-'Ajamī, “Thabat”, AUB MS:297.124:S941tA, 9, 12, 212-213, 593-596.

14 Sibț Ibn al-'Ajamī, "Thabat”, AUB MS:297.124:S941tA, 286.

15 Sibț Ibn al-'Ajamī, “Thabat”, AUB MS:297.124:S941tA, 40, 599-600.

16 Ibn Maymūn al-Balawī died in Yemen in 792 H/1389-90 CE. See Ibn al-Jazarī, Ghāyat alnihāya (1933), 2: 255; Ibn Ḥajar, al-Durar (1993), 4: 232; al-Burayhī, Ṭabaqāt (1994), 253; Ibn Qāḍī Shuhba, Ta'rikkh (1988), 3: 413. 
closely over such a long period of time. Ibn Maymūn al-Balawī was probably around the same age as Sibt Ibn al-'Ajamī. They also had similar interests in reading hadith which, no doubt, brought them closer to each other and allowed them to pursue their studies together. Ibn Maymūn al-Balawī arrived in Damascus in 772 H/1370-1 CE from Tunis, after having left Granada a year earlier. ${ }^{17} \mathrm{He}$ had never met Ibn Hizb Allāh but on the list of his Granada teachers are found scholars who certainly had. ${ }^{18}$ For about 13 years he wandered between Damascus, Aleppo and Cairo, studying and teaching hadìth and qirā'āt. Similarly to Sibṭ Ibn al-'Ajamī, he carried with him a holograph ijāzas, from his Andalusi teachers, which he showed to his Mamlūk colleagues. ${ }^{19}$ It would be more speculation to suggest that this might have played any role in Sibṭ Ibn al-'Ajamì's desire to have a similar holograph ijāza by Ibn Hizb Allāh. However, what is more certain is that it had to have been Ibn Maymūn al-Balawī who introduced him to Ibn Hiizb Allāh in $784 \mathrm{H} / 1382 \mathrm{CE}$, when the two old friends ran into each other in Damascus.

\section{Ibn Ḥizb Allāh's meeting with Sibṭ Ibn al-'Ajamī and Ibn Maymūn al-Balawī in Damascus}

Despite Ibn Hiizb Allāh being a relatively unknown scholar, he is arguably one of the most curious Andalusis one could have encountered in Damascus. ${ }^{20} \mathrm{He}$ was a former member of the chancery of the Marinid sultans, a veteran of one of the largest battles of the 14th century, the Battle of Tarifa (741 H/1340 CE), and he is known to have participated in the Marīnid conquest of Qusanțina in $758 \mathrm{H} /$ 1357 CE. He was probably born in Wādī Āsh (Guadix) in 712 H/1312-3 CE where his father worked as an 'adl (notary). ${ }^{21}$ After a long period of service in al-Andalus and Maghrib, he left on pilgrimage and settled in Jerusalem for almost 30 years.

17 Ibn al-Jazarī, Ghāyat al-nihāya (1933), 2: 29, 210

18 Namely Aḥmad Ibn Khātima, Abū al-Barakāt al-Balafìqī or Faraj Ibn Lubb.

19 It is Ibn al-Jazarī who mentioned that al-Balawī had brought the ijāzas of some scholars with him, such as Ibn Lubb or Ibn Qāsim al-Ghassānī. These ijāzas were clearly his cultural capital in the Mamlūk territory. See Ibn al-Jazarī, Ghāyat al-nihāya (1933), 1: 97; 2: 8

20 Ibn al-Khațīb, Awṣāf al-nās (2002), 143; Ibn al-Khațīb, al-Iḥāta (2001), 2: 367-370. For corrections see Ibn Tāwìt al-Ṭanjī 1979, 343-344; al-Bishtakī, "Markaz al-Iḥāta”, BnF Arabe 3347, fol. 27r-27v; al-'Ulaymī, al-Uns (1999), 2: 362-363; Ibn Ḥajar, Inbā' al-ghumr (1972), 1: 328; Ibn Ḥajar, al-Durar (1993), 4: 199-200; Ibn al-Ḥājj, Fayḍ al- 'ubāb (1990), 322; Ibn al-Aḥmar, Nathïr al-jumān (1987), 426; Damaj 2004, 160.

21 Espinar Moreno 2019, 87-88. 
He died in Damascus in $788 \mathrm{H} / 1386 \mathrm{CE}$. History has largely forgotten him now but during the three days of Sha'bān 784/October 1382 in Damascus he created an extraordinary document when he met Ibn Maymūn al-Balawī and Sibṭ Ibn al'Ajamī.

The story of how these three men met can be reconstructed based on seven pages of Sibt Ibn al-'Ajamì's Thabat (pages 568-574) written either in the handwriting of Ibn Hizb Allāh or at his request by Ibn Maymūn al-Balawī. ${ }^{22}$ The whole sojourn of Sibț Ibn al-'Ajamī in Damascus covers 16 pages (pages 564-579), which means that Ibn Hizb Allāh's text occupies half of this juz'. Page 564 is the frontpage of his arrival in Damascus in which Ibn Hizb Allāh is listed as a teacher. Pages 565 to 567 contain samā'āt, qirā'āt and inshādāt from 28 Rajab 784/7 October 1382 (page 565), the end of Rajab 784/October 1382 (from pages 565-567) and the first day of Sha 'bān 784/10 October 1382 (page 567). One folio follows up with an excerpt from Ibn Hiizb Allāh's Riḥla, written in the handwriting of Ibn Maymūn al-Balawī (pages 568-569), confirmed at the bottom of the second page (page 569) by Ibn Ḥizb Allāh with an ijāza dated on 5 Sha'bān 784/14 October 1382. The paper of this folio appears to be a bit smaller than the rest of this section of the Thabat and the ink and pen seems to be different from the ones used for the ijāzas on pages 570 to 573, granted by Ibn Ḥizb Allāh one day earlier on Sha 'bān 4, 784/October $13,1382 .{ }^{23}$ On page 574 there is a third ijāza given by Ibn Hizb Allāh to Sibṭ Ibn al-'Ajamī’s friend, Abū al-Ḥasan 'Alī Ibn Bahrām al-Ḥalabī, dated 6 Sha 'bān 784/15 October 1382. The pen used by Ibn Ḥizb Allāh differs from the one used in the main body of the text of the first ijāza. Page 575 is blank. The following three folios (pages 576 to 579) contain samā' $\bar{a}$ t and qirā'āt dated 4 Sha'bān 784/13 October 1382 (page 576) or 6 Sha'bān 784/15 October 1382 (pages 577-578), as well as the list of works included in this juz' along with two long notes.

Ibn Hiizb Allāh informs us that he came to Damascus, most likely from Jerusalem (nazil Bayt al-Muqaddas) where he lived. ${ }^{24}$ In the span of three days, he met with Sibt Ibn al-'Ajamī at least three times. He does not mention where in Damascus the meetings occurred, nor can it be inferred from Sibṭ Ibn al-'Ajamī's sessions with other scholars in the same period. On 4 Sha 'bān Sibṭ Ibn al-'Ajamī had

22 Sibț Ibn al-'Ajamī, "Thabat”, AUB MS:297.124:S941tA, 568-574. For the edition see Appendix I.

23 Ibn Hiizb Allāh used the same pen and ink to correct the first ijāza.

24 See Appendix I. 
a session in the private house of one of his teachers in Darb al-Sharif at the great market and on 6 Sha'bān he is found at the madrasa al-Iqbāliyya. ${ }^{25}$

In the introduction to the first ijāza (on 4 Sha'bān), Ibn Ḥizb Allāh discussed the reasons why he was not able to fulfill Sibt Ibn al-'Ajamì's wish to obtain some of his work written in his handwriting. He implies that he did not have his papers with him, and there was not enough time, therefore, he could not satisfy the wishes of the Aleppan scholar. Instead, he recited from memory some of his poetry included in his Rihla, covering his travels from the Maghrib to Damascus. Then he asked his companion in God, Ibn Maymūn al-Balawī, to collect something from his writings for Sibț Ibn al-'Ajamī, thus revealing that there was a previous relationship of some kind between the two Andalusi scholars. In this ijāza, Ibn Ḥizb Allāh gave Sibṭ Ibn al-'Ajamī permission to transmit, on his authority, his Rihla.

The following day, he granted Sibt Ibn al-'Ajamī another ijāza written at the bottom of the folio along with a chapter from Ibn Hiizb Allāh's Riḥla on Cairo. Ibn Maymūn al-Balawī copied it from some papers but it is unclear whether they were his own or belonging to Ibn Hizb Allāh. He used his typical "adapted” Andalusi handwriting with $f \bar{a}^{\prime}$ with one dot above the letter and the $q \bar{a} f$ with two as in the eastern scripts, and reveals its title: al-Rawḍa al-arị̂a al-hizbiyya wa-l-rị̣la algharbiyya al-gharība wa-tatlūhā al-hijāziyya wa-l-shāmiyya. The introduction is full of praise for its author and there had to be a session in which Ibn Hizb Allāh read some of the Rihla since the author made addenda to the first ijāza in his own handwriting on the second day. ${ }^{26}$

After the second day, Sibt Ibn al-'Ajamī showed two ijāzas, or at least mentioned them to his Aleppan companion on this journey, one Abū al-Hasan Ibn Bahrām al-Ḥalabī. On the following, third, day, Ibn Ḥizb Allāh granted another ijāza to this Abū al-Hasan and gave him permission to transmit the chapter in the description of Mișr ${ }^{27}$ taken from al-Rihla al-ḥizbiyya. However, he was silent about reading the work with $\mathrm{Abu}$ al-Hasan or even meeting him in person. ${ }^{28}$

This chance encounter of these three men resulted in a lively interaction between Andalusi and Mamlūk scholars and led to the creation of an extraordinary historical source. Ibn Maymūn al-Balawī knew both of them and it was he who

25 Sibț Ibn al-'Ajamī, “Thabat”, AUB MS:297.124:S941tA, 576 (Darb al-Sharīf; for its location see Ibn Ḥijji, Ta’rīkh [2003], 1: 105); 577 (al-madrasa al-Iqbāliyya; see Miura 2016, Table I-9, 40).

26 See Appendix I for the emendations.

27 Ibn Ḥizb Allāh distinguishes between al-Qāhira (Cairo) and Mișr (the city founded by 'Amr). He did not mention al-Qāhira in this ijāza (nor in his confirmation at the bottom of the chapter copied by Ibn Maymūn al-Balawī).

28 Sibṭ Ibn al-'Ajamī, “Thabat”, AUB MS:297.124:S941tA, 574. 
was responsible for introducing them to each other. This is clear from some addenda to Sibt Ibn al-'Ajamì's name by Ibn Hizb Allāh later on the second day, demonstrating his unfamiliarity with his first name. ${ }^{29}$ Ibn Maymūn al-Balawī seems to be very proud of his much older and (once) much more important compatriot. Granting Sibț Ibn al-'Ajamì's request for an ijāza provided the opportunity to pass on some Western culture to him and Ibn Hizb Allāh took his chance to show to Sibt Ibn al- 'Ajamī who he once was before he had come to the East.

\section{Ibn Ḥizb Allāh as pictured by himself and by lbn Maymūn al-Balawī}

The earliest fragment of Ibn Ḥizb Allāh, given to Sibṭ Ibn al-'Ajamī on 4 Sha 'bān $784 / 13$ October 1382 should be considered above all as an ego-document in which he was given a forum to present a picture of himself to his student, Sibt Ibn al'Ajamī, and in front of a scholar, Ibn Maymūn al-Balawī, who was familiar with the environment in which he had acquired and practiced his skills. Its importance is as much visual as textual since Sibt Ibn al-'Ajamī wished to have it written in Ibn Hiizb Allāh's own handwriting. After all, he was a former Marinid kātib. In this profession, the form, the expression, and the visual aspect went hand in hand. Ibn Hizb Allāh's handwriting had already acquired great fame in the West, as attested by Ibn al-Khațīb in his biographical sketch of Ibn Ḥizb Allāh. Certainly, the Granadan polymath and ra'îs al-kuttāb (chief of the royal chancellery) could easily evaluate this particular skill of his friend as his familiarity with the contemporary hands of the Western chancery scribes was immense. ${ }^{30}$ The introduction to the first two verses in which Ibn Hizb Allāh made a claim to be the kātib al-sirr (the personal chancellor) to the Marīnid sultan, Abū 'Inān Fāris (r. 749-759 H/ 1348-1358 CE), clearly points to this group identity of the Maghribi kātibs.

Ibn Ḥizb Allāh's self-designation as an important member of the sultan's chancery forms one of the two main recurring themes introduced in his texts. ${ }^{31}$ The second is the reason why, and how, he left this office and established himself in the East. While the former is not confirmed by any other source, he is only one of many kātibs of the Marīnid court, this latter point is proven by Ibn Hizb Allāh's

29 Sibț Ibn al-'Ajamī, “Thabat”, AUB MS:297.124:S941tA, 570.

30 I have already discussed this issue in my previous article. See Ženka 2018, 352-353. For Ibn al-Khațīb see Lirola Delgado et al. 2004.

31 Megill 2007, 44-46. 
life in the East, as well as by Ibn al-Khațīb. ${ }^{32}$ In these two subjects Ibn Hiizb Allāh defines what he was, and still is, and how it happened that he found himself where he was, using his past to describe his present by means Ibn Maymūn alBalawī would certainly expect from a scholar of his training and experience.

Regarding the first theme, the four poems (out of a total of seven), with their introductions, tackle his intimate relationship with sultan Abū 'Inān Fāris. The first is Ibn Hizb Allāh's statement about his motives in leaving the sultan's services. He elaborates on his role at the court in the fifth, sixth, and seventh poems. The fifth poem narrates the story of Abū 'Inān Fāris killing a lion and how other poets composed verses in praise of the sultan. Ibn Hizb Allāh recited his only after the sultan asked him to do so. The story in the two following is intertwined. Ibn Hiizb Allāh starts with two verses recited by another Marīnid kātib, Abū 'Abd Allāh al-'Azafī (699-768 H/1300-1366 CE). ${ }^{33}$ He describes how he told Abū 'Abd Allāh al-'Azafi that the recitation of the two verses in the presence of the sultan was inappropriate and that they had omitted important topics. He was asked to recite better ones, which he did, and all who heard him, including the sultan, were pleased. By quoting conversations between the sultan and himself, Ibn Hizb Allāh shows the intimate nature of his relationship with the ruler and his importance at the court. Indeed, Ibn al-Ḥājj al-Numayrī (712-ca. 785 H/1312-3-ca. 1383 CE) places Ibn Hizb Allāh among other members of the chancery who also were involved in the recitation of poetry after the conquest of Qusanțina, not long before Ibn Hizb Allāh left for the East. ${ }^{34}$

The second theme is his travel to, and establishment in, Jerusalem. In the first poem he alludes to the desire to devote his life to God as the reason why he had left. However, the introduction to the third poem is the only place where he mentions hajj (pilgrimage) and ziyāra (visit to Medina) as the excuse for leaving Maghrib. Other Marīnid and Nașrid officials, such as Ibn Marzūq (710 or 711-781 H/ 1310-2-1379-80 CE), ${ }^{35}$ Ibn Kumāsha (d. after 787 H/1385 CE), ${ }^{36}$ Ibn al-Khațīb (713$776 \mathrm{H} / 1313-1374 \mathrm{CE}),{ }^{37}$ and Ibn Khaldūn (732-808 H/1332-1406 CE) ${ }^{38}$ used the same rationale for removing themselves from the dangers of political life in Maghribi courts. In a fragment of the Riḥla, Ibn Ḥizb Allāh dated his arrival in Cairo and Egypt as 15 Shawwāl 760/9 September 1359. This and his quotation of a very

32 Ibn al-Khațib, al-Katība (1983), 274-275.

33 For Abū 'Abd Allāh al-'Azafī see Rodríguez Figueroa 2012.

34 Ibn al-Ḥājj, Faỵ̣ al- 'ubāb (1990), 322; Ibn al-Aḥmar, Nathīr al-jumān (1987), 426.

35 For Ibn Marzūq see Peláez Rovira 2006.

36 Ibn al-Khațīb, al-Ihāta (2001), 4: 75-76.

37 Calero Secall/Roser Nebot 2001, 422-423.

38 Manzano Rodríguez 2004, 584-585. 
specific Qur'ānic verse (12.99) in Riḥla provide a hint that his withdrawal from the Marinid court and the Maghrib might have been caused by the political turbulence that followed the death of sultan Abū 'Inān Fāris in 759 H/1358 CE. ${ }^{39}$ Like Ibn Khaldūn and Ibn Marzūq, he never returned.

Ibn Hizb Allāh, however, remains silent about his situation after the murder of the sultan. Nor does he give much detail about his life in the East, his prior education or teachers. He states that he settled in Jerusalem (nazil Bayt al-Muqaddas) and was only on a visit to Damascus (called here Jilliq). In the early 770s $\mathrm{H} /$ 1370s CE, Ibn al-Khatiib, then exiled in Fez, knew that he lived peacefully in the Mashriq but at a distance from politics and without any connection to the ruling dynasty. This means that someone from the West had to have visited Ibn Hizb Allāh and brought the news back to the Marīnid court. ${ }^{40}$ His relationship with Ibn Maymūn al-Balawī, referred to previously, also suggests that he did maintain ties with some scholars from the West.

Ibn Maymūn al-Balawì's involvement in the ijāzas, as well as in selecting a specific fragment of the Rihla, emphasizes the Andalusi connection, the meaning of Ibn Hizb Allāh's texts, and demonstrates his reception of this text. By giving the full title of the work, Ibn Maymūn al-Balawī confirms that the travelogue covered Ibn Hiizb Allāh's journeys not only in the East, but also in the West. Ibn Hizb Allāh himself pointed this out in his first ijāza, saying that it ends in Damascus and contains all the fragments recited by him to Sibt Ibn al-'Ajamī and is comprised of poetry, stories, and quotations of other works. Thus, its contents resemble the travelogue of his contemporary, Ibn al-Hājj al-Numayrīin ${ }^{41}$, or another younger colleague, Ibn Khaldūn, yet its literary form is closer to that of Ibn alKhațīb’s Khațrat al-țayf. ${ }^{42}$ Again, the language used by Ibn Hiizb Allāh demonstrates his excellent qualities as a kätib and his mastery of ornate vocabulary and rhyming prose.

In his introduction to the selected chapter of Riḥla, Ibn Maymūn al-Balawī attributes the name Ibn Ḥizb Allāh al-Andalusī al-Wādī Āshī al-Ṭā'ì, in contrast to Ibn Ḥizb Allāh's own self-designation as Ibn Ḥizb Allāh al-Wādī Āshī al-Ṭā'ī

39 Sibṭ Ibn al-'Ajamī, “Thabat”, AUB MS:297.124:S941tA, 568. Either Ibn Ḥizb Allāh or Ibn Maymūn al-Balawī corrected in the manuscript the Qurā'nic quotation from a verse 2.61 (ihbițū mișran - Get you down to Egypt; translations follow A. J. Arberry) to 12.99 (idkhulū miṣr - Enter you into Egypt). I would argue that there might be some paralles between the story developed around the latter and Ibn Hiizb Allāh's own.

40 "He established himself in the Mashriq, unpledged to anyone, not bounded to the power nor tied to the ruling dynasty” (Ibn al-Khațîb, al-Katība [1983], 274-275).

41 On Ibn al-Ḥàjj al-Numayrī see Lirola Delgado/López y López 2004.

42 Ibn al-Khațīb, Khațrat al-țayf (2016). 
only. ${ }^{43}$ Clearly, Ibn Maymūn al-Balawī was aware that this text belonging to the Mamlūk scholar, Sibt Ibn al-'Ajamī, would travel with him. By adding 'al-Andalusî' he clarified for other readers that Wādī Āsh (Guadix) was in al-Andalus. The selection of the chapter on Cairo and Miṣr was also not a coincidence. Both Ibn Maymūn al-Balawī and Sibt Ibn al-'Ajamī were on their way to this city and one might reasonably assume that Ibn Maymūn al-Balawī hoped that, as with his previous browsing and use of Sibt Ibn al-'Ajamī's Thabat, other local Mamlūk scholars would benefit from it. This would also explain the use of so many honorific titles by Ibn Maymūn al-Balawī to describe Ibn Hiizb Allāh; to help the Mamlūk audience truly appreciate his qualities as a scholar and literary figure. The request of Sibṭ Ibn al-'Ajamī can be seen as the reason why Ibn Hizb Allāh added his date of birth (712 H/1312-3 CE) at the end of the first ijāza. This type of information was often requested by Sibț Ibn al- 'Ajamī from his teachers and, later, in some cases but not in Ibn Hizb Allāh's, amended with the date of their death.

In short, Ibn Maymūn al-Balawī not only understood Ibn Hiizb Allāh's past but he also connected it to the present. On the other hand, Ibn Hizb Allāh used his skills to write exclusively about his past that he saw as defining him. He created an image of himself for Sibt Ibn al-'Ajamī by employing another strategy, used by many Maghribi kātibs, in writing history and deciding how people should be remembered and viewed. In the second half of the 8th/14th century, it was kātibs at different Maghribi courts who authored chronicles and biographical dictionaries. They played a key role in creating and shaping an image of their contemporaries for the future. Ibn Hizb Allāh grew up and worked with many of them, and clearly he was capable of doing the same. ${ }^{44}$ The resulting work circulated in the Mashriq, and it was Sibț Ibn al-'Ajamī who played such a major role in how Ibn Hizb Allāh's reception and understanding changed over the remaining part of his life.

43 Sibț Ibn al-'Ajamī, “Thabat”, AUB MS:297.124:S941tA, 568 and 570.

44 For instance, he served with Abū 'Abd Allāh Muḥammad Ibn Juzayy (721-757 H/13211356 CE) who started to write a history of al-Andalus (Velázquez Basanta 2009a; Molina 2015), or with Ibn al-Hāijj al-Numayrī who narrated the history of the Marīnid conquest of North Africa during the reign of sultan Abū 'Inān Fāris. See Ibn al-Ḥājj al-Numayrī, Faỵ̣ al- ‘ubāb (1990). 


\section{Ibn Ḥizb Allāh's ijāzas in Aleppo}

After a significant stay in Cairo, Sibṭ Ibn al- 'Ajamī returned to Aleppo on 26 Shawwāl 786/11 December 1384. ${ }^{45}$ Over the years, his Thabat had become very wellknown. As one of the most renowned muhaddith of his times, and certainly as the most pursued hadith teacher of Aleppo, he used his manuscript constantly during his classes and allowed his students to copy its contents directly. A closer inspection of the thabats of four of his disciples reveals that he taught and transmitted Ibn Hizb Allāh's work, or parts of it, at least twice: once to Abū al-Faḍl Muhammad Ibn al-Shiḥna (804-890 H/1402-1485 CE) in 828 H/1425 CE, and another time to Ibn al-Nașībī's brothers, Abū Hafṣ 'Umar (823-873 H/1420-11469 CE) and Abū Bakr 'Abd Allāh (824-893 H/1421-1488 CE), in 839 H/1436 CE. ${ }^{46}$ The detailed information noted by his disciples in their manuscripts facilitates a reconstruction of the ways in which his work was transmitted in its horizontal context. This, consequently, enables the exploration of the changing perceptions and meanings of Ibn Hizb Allāh's text and the possible reasons that led Sibt Ibn al-'Ajamì to transmit the work at that particular moment.

The earliest recorded transmission of Ibn Hizb Allāh's texts occurred on 24 Ramaḍān 828/9 August 1425 in the madrasa al-Sharafiyya of Aleppo. ${ }^{47}$ The session consisted of several parts, and Ibn al-Shihna gives full details of the group of students meeting with Sibț Ibn al-'Ajamī. Besides Sibț Ibn al-'Ajamī and Ibn alShiḥna, there were local judges, Shihāb al-Dīn Abū Ja'far al-'Ajamī (775-857 H/ 1373-1457 CE) and Șalāh al-Dīn Ibn al-Naṣībī (781-857 H/1380-1453 CE), the latter accompanied by his son, Kamāl al-Dīn Ahmad, a certain Sa'd al-Dīn Sa 'īd and a scholar from Tunis, Abū al-Barakāt Muhammad b. Muhammad b. Muhammad b. 'Azūz al-Anșārī al-Tūnisī al-Maghribī (d. 873 H/1468-9 CE). ${ }^{48}$ In the first part, Sibṭ Ibn al-'Ajamī informed his students about Ibn Hịb Allāh's Riḥla. ${ }^{49}$ In the next, he recited poetical fragments by Ibn Hiizb Allāh. ${ }^{50}$ Ibn al-Shihna introduced the first poem with the words anshadana shaykhunā, whereas the remaining ones only had wa-bihi qāla, making it impossible to distinguish whether Sibt Ibn al-

45 Sibt Ibn al-'Ajamī, “Thabat”, AUB MS:297.124:S941tA, 612.

46 The other two thabats examined for this study belonged to Muhammad al-Salāmī (Universitätsbibliothek Leipzig MS Vollers 721) and Ibn Zurayq (Princeton Garrett MS 178B). For the latter see Richardson 2016.

47 Ibn al-Shiḥna, “Thabat”, Jāmi'at al-imām MS 7235, fols. 87r, 88r, 88v and 89v.

48 Ibn al-Shihnna, "Thabat”, Jāmi'at al-imām MS 7235, fol. 87r-v.

49 Ibn al-Shihnna, "Thabat”, Jāmi'at al-imām MS 7235, fols. 86r-87v.

50 Ibn al-Shiḥna, “Thabat”, Jāmi'at al-imām MS 7235, fols. 87v-88r 
'Ajamī recited everything, or just the first poem and then let Ibn al-Shihna copy the rest from his Thabat. A note in the bottom left margin (fol. 88r), right after the conclusion of this part of the session, gives the following testimony to the copying process: "I transcribed everything from the handwriting of the aforementioned Ibn Hizb Allāh except the part describing Mișr. I copied it from the handwriting of al-Balawī". ${ }^{51}$ Further evidence for the process of transmission of Ibn Hizb Allāh's text appears in the penultimate line in folio 88r when Ibn al-Shihna started to copy the concluding remarks of Ibn Hizb Allāh (fa-sarra al-jamī'u bidhālika fa-nqați $u$ ) before crossing it out after writing fa-sarra al-j only..$^{52}$ Likewise, he ignored all three of Ibn Hizb Allāh's confirmations and his introduction that described the circumstances of his meeting with Sibt Ibn al-'Ajamī.

Apparently only the literary texts, the fragment of Rihla, and the poetry, with its introductions, had any importance for Ibn al-Shihna, thus changing considerably not only the length of the text but also the ego-expression of Ibn Hizb Allāh. His access to the holograph text of this Thabat points to the possibility of Sibt Ibn al-'Ajamī recounting to his audience details about the encounter with Ibn Hizb Allāh many years previously. However, in the text copied by Ibn al-Shihnna, the Andalusi kätib loses the sense of being a real person with a story behind him, including that of the transmission of his work in Damascus, thus, becoming only an author of poetry and rihla in rhymed prose. This was the only part valued by the students and, as might be implied, was the subject of this scholarly session.

In addition, further contents of this majlis (session) reveals a certain pattern in which Sibṭ Ibn al-'Ajamī taught Ibn Ḥizb Allāh's work in conjunction with other Andalusi material. This can be confirmed by several other poetical fragments recited by Sibt Ibn al-'Ajamī during other parts of the same session, transmitted to him by another Andalusi scholar, Abū al-Ḥasan 'Alī b. Abī Mahdī 'Īsā b. Muhammad al-Fihrī al-Basṭī al-Yumnālī (d. 819 H/1416-7 CE). ${ }^{53}$ Six of them were composed by this scholar himself and two separate poetical fragments by Abu Muhammad 'Abd Allāh Ibn Juzayy (731-810 H/1331-1407 CE). ${ }^{54}$ Sibṭ Ibn al-'Ajamī

51 Ibn al-Shiḥna, "Thabat”, Jāmi'at al-imām MS 7235, fol. 88r.

52 Ibn al-Shiḥna, “Thabat”, Jāmi'at al-imām MS 7235, fol. 88r.

53 Ibn al-Shiḥna, "Thabat”, Jāmi'at al-imām MS 7235, fols. 88v-89v.

54 I quote the word al-Yumnālī as given by Sibṭ Ibn al-'Ajamī. See Sibṭ Ibn al-'Ajamī, "Thabat”, AUB MS:297.124:S941tA, 626 (for the name) and 627 (for Ibn Juzayy). For al-Fihrī al-Basțī see Sibṭ Ibn al-'Ajamī, "Thabat”, AUB MS:297.124:S941tA, 626-627; Ibn Ḥajar, Dhayl al-Durar (1992), 247; Ibn Ḥajar, al-Durar (1993), 3: 92-93; Ibn Ḥajar, Inbā' al-ghumr (1972), 3: 112; al-Sakhāwī, al-Daw' (1992), 5: 283-284; Ibn Khațīb al-Nāṣiriyya, “Al-Durr al-muntakhab”, BnF Arabe 2139, fols. 44b45a; al-Suyūṭī, Bughyat al-wu'āt (1979), 2: 182. Al-Fihrī al-Basțī authored a work named Zahrat al-ādāb wa-tuhfat ūlā al-albāb (Bibliotheca Alexandrina MS 892.7). As far as I know, only 
met al-Fihrī al-Basṭī in 790 H/1388 CE and learned these verses and several others by his Andalusi teachers Abū al-Barakāt al-Balafīqī (680-771 H/1281-2-1370 CE) and Abū al-Ḥasan Ibn al-Jayyāb (673-749 H/1274-1349 CE)..$^{55}$ Ibn al-Shihnna had already heard of al-Fihrī al-Basṭī when on 27 Dhū al-Ḥijja 826/1 December 1423, Sibt Ibn al-'Ajamī recited to him a poem by the ra'îs al-kuttāb of Granada Ibn alJayyāb. ${ }^{56}$ The question is why Sibt Ibn al-'Ajamī decided to teach and recite from Ibn Ḥizb Allāh and al-Fihrī al-Basṭi in Ramaḍān 828/August 1425. The answer seems to lie in the presence of a Maghribi scholar, Abū al-Barakāt Ibn 'Azūz alAnșārī al-Tūnisī..$^{57}$

In a page inserted between the tenth and eleventh parts of the Thabat that has a sample of Ibn 'Azūz's handwriting, alongside a long accompanying note, Ibn al-Shihna demonstrated how the distinctive handwriting of a Western traveler appealed to an Aleppan scholar and how the presence of a strange guest led to intellectual exchanges between him and local scholars. ${ }^{58}$ Ibn 'Azūz clearly came to the city at the beginning of Ramadān to study with local scholars such as Sibṭ Ibn al-'Ajamī and Ibn Khațīb al-Nāṣiriyya (774-843 H/1372-1440 CE). Ibn alShihna narrates how they attended various sessions together and how Ibn 'Azūz asked for some of his father's works, ${ }^{59}$ as well as other texts, to be written in Ibn al-Shihna's own handwriting into his Thabat. ${ }^{60}$ In exchange, the Tunisian scholar reciprocated with three verses by Taqī al-Dīn Ibn Daqīq al- '⿳亠'd (625-702 H/1228$1302 \mathrm{CE}$ ) accompanied with isnād (chain of transmitters). Furthermore, Ibn alShihna supplies two important pieces to the puzzle; he records Ibn 'Azūz's lodging as being in the madrasa al-Sharafiyya and provides the date of his departure from Aleppo as 26 Ramaḍān 828/11 August 1425, two days after Ibn Hiizb Allāh’s and al-Fihrī al-Basțī's texts/transmission were discussed in the same madrasa. In

Thomas Bauer used it in one of his articles. See Bauer 2007, 303-304. See also Brockelmann 2017, 13. For Ibn Juzayy see Velázquez Basanta 2009b.

55 Sibț Ibn al-'Ajamī, "Thabat”, AUB MS:297.124:S941tA, 626-627.

56 Ibn al-Shiḥna, “Thabat”, Jāmi'at al-imām MS 7235, fols. 25v and 26r. On Ibn al-Jayyāb see Rubiera Mata/Kalaitzidou 2009.

57 Al-Sakhāwī wrote several biographical sketeches of Ibn 'Azūz. See al-Sakhāwī, al-Daw' (1992), 10: 16; al-Sakhāwī, al-Dhayl (1992), 2: 224; al-Sakhāwī, Wajīz al-kalām (1995), 2: 804.

58 Ibn al-Shihnna, “Thabat”, Jāmi'at al-imām MS 7235, fol. 83v. Sibț Ibn al-'Ajamī followed the same practice, although without including a specimen of handwriting, when al-Fihrī al-Basțī came to Aleppo. In the page with his transmission he added a long note detailing his visit to Aleppo, later wanderings, and fate in the East until the year 817 H/1414-5 CE. See Sibt Ibn al'Ajamī, “Thabat”, AUB MS:297.124:S941tA, 626-627.

59 Ibn al-Shihnna's father, Abū al-Walīd Muhammad (749-815 H/1348-1412 CE), was an important local scholar and author.

60 Ibn al-Shiḥna, “Thabat”, Jāmi'at al-imām MS 7235, fol. 83v. 
other words, Sibṭ Ibn al-'Ajamī presented his knowledge of some Maghribi poetry and, in a moment reminiscent of what Ibn Hiizb Allāh did for him many years previously, passed on the work to Ibn 'Azūz.

The argument for Ibn Ḥizb Allāh’s works being used by Sibṭ Ibn al-'Ajamì when Maghribi scholars visited him in Aleppo is strengthened by the second case, the only surviving juz' (al-juz' al-thālith min masmū' Halab) of the Thabat written in the handwriting of Abū Hafṣ 'Umar Ibn al-Nașībī, who makes the point perfectly clear. ${ }^{61}$ It covers the end of Shawwāl and the month of Dhū al-Qa'da 839/May-June 1436, when the incumbent Mālikī chief judge of Hamā, Muhammad al-Hakamī (806-840 H/1403-4-1437 CE), ${ }^{62}$ paid a visit to Aleppo to read hadìth with Sibt Ibn al-'Ajamī. ${ }^{63}$ Al-Hakamī was originally from Labasa (La Peza) in al-Andalus, a castle lying very close to the city of Wādī Āsh (Guadix), the native city of Ibn Ḥizb Allāh. ${ }^{64}$ Sibṭ Ibn al- 'Ajamī's son, Abū Dharr Aḥmad (818$884 \mathrm{H} / 1415-1480 \mathrm{CE}$ ), accommodated him in his house in the madrasa alSharafiyya. Later, he authored a large biographical sketch of this Andalusi scholar, providing the necessary background material for an understanding of the third documented transmission of Ibn Hizb Allāh's work. ${ }^{65}$

In the Masmū' of Abū Hafṣ 'Umar Ibn al-Nașībī, a poem of Ibn Ḥizb Allāh is found among other Andalusi poetry recited by Muhammad al-Hakamī. ${ }^{66}$ He says that the Shaykh Ibrāhīm (i.e. Sibt Ibn al-'Ajamī) recited a poem to him, later adding his full name above the word. He then wrote down the fifth poem of Ibn Hizb Allāh's fragment and stated that this recitation occurred on 8 Dhū al-Qa'da

61 This Thabat was penned by Abū Ḥafṣ 'Umar Ibn al-Nașībī, but the listening and reading certificates also belonged to his brother, Abū Bakr 'Abd Allāh. Both of them were sons of the judge, Șalāh al-Dīn Ibn al-Nașībī, who attended Sibț Ibn al-'Ajamī's session in 828 H/1424 CE where he transmitted the works of Ibn Hiizb Allāh.

62 Sibṭ Ibn al-'Ajamī, Kunūz al-dhahab (1996), 1: 484-486; al-Sakhāwī, al-Ḍaw' (1992), 10: 2627 (biography), see also 4: 205-206 and 7: 235; al-Sakhāwī, al-Dhayl (1992), 1: 603.

63 Ibn al-Nașībī, "Masmū' Ḥalab", Bibliotheca Alexandrina MS 297.124. The earliest majlis included in this juz' dates to the last ten days of Shawwāl 839/May 1436 (fol. 1v). Muhammad alHakamī was the reader. The last one dates from 20 Dhū al-Qa'da 839/5 June 1436 (fol. 12v). The listening and reading certificates are not bound by chronological order.

64 According to Abū Dharr Aḥmad, al-Ḥakamī stayed in Aleppo from 16 Shawwāl to 17 Dhū alQa'da 839/3 May-2 June 1436 (Sibț Ibn al-'Ajamī, Kunūz al-dhahab [1996], 1: 484, 486). Ibn alNașībī's Masmū' Halab, however, situate him in Aleppo until at least the 20th of that month. See Ibn al-Nașībī, "Masmū' Ḥalab”, Bibliotheca Alexandrina MS 297.124, fol. 12v.

65 Sibț Ibn al-'Ajamī, Kunūz al-dhahab (1996), 1: 484-486.

66 Ibn al-Nașībī, "Masmū' Ḥalab”, Bibliotheca Alexandrina MS 297.124, fols. 7b-8r. See Appendix II. 
839/24 May $1436 .{ }^{67}$ Later, he added below this text and to the facing page some other Andalusi poems recited to him by Muhammad al-Hakamī with the following note: 68

He recited all the poetry quoted here during his travel to Aleppo in my very presence. The motive of his mentioned travel from Hama was to study with al-imām al-ḥäfiz Burhān alDīn Ibrāhīm al-Ḥalabī Sibț Ibn al-'Ajamī. ${ }^{69}$

It is clear that the recitation of Ibn Hizb Allāh's poem formed part of the poetical exchanges in which Sibt Ibn al-'Ajamī and Muhammad al-Hakamī were involved in the presence of their students, Ibn al-Nașībī and Abū Dharr Ahmad. ${ }^{70}$ Secondly, the corrigenda of Ibn Ḥizb Allāh's name in Masmū ', where Ibn al-Nașībi corrected it from Shams al-Dīn b. Ḥizb Allāh al-Wādī Āshī to Shams al-Dīn Muhammad b. Muhammad b. 'Alī b. Ḥizb Allāh al-Wādī Āshī by writing the missing nasab above the word "al-din", indicates that the Thabat with the original version was present during the sessions and was at the disposal of the participants. Thirdly, by omitting the introduction to the poem, opting for a simple "wa-anshadana al-shaykh Ibrāhīm al-madhkūr qāla anshadanā al-shaykh Shams al-Dīn/ Muḥammad b. Muhammad b. 'Alī b. Hizb Allāh al-Wādì Āshì li-nafsihi' (the mentioned shaykh Ibrāhīm said: Ibn Hiizb Allāh recited us by himself), Ibn Ḥizb Allāh’s ego-identity disappeared, and for Ibn al-Nașībī he remained only a name introducing two verses of poetry. This brevity is similar to that employed by Abū Dharr Ahmad Sibț Ibn al-'Ajamī in Kunūz al-dhahab for the introduction to other poems recited by Muhammad al-Ḥakamī during his visit to Aleppo. ${ }^{71}$

On the other hand, for Muhammad al-Hakamī the importance and identity of Ibn Hiizb Allāh had to be perfectly clear, even at first glance. Given that he was trained in al-Andalus by the most renowned teachers of the time, he must have known that he was looking at a handwriting of a scholar trained in dīwān al-in$s h \bar{a}^{\prime}$ with close ties to the palace. In contrast to his Mashriqi friends, Muhammad al-Ḥakamī was the only person present in Aleppo in a position to be able to fully

67 Ibn al-Nașībī, “Masmūc Ḥalab”, Bibliotheca Alexandrina MS 297.124, fol. 8r.

68 Muhammad al-Ḥakamī recited a verse attributed by Abū Ḥafṣ 'Umar Ibn al-Nașībī to Abū 'Alī al-Tha 'labī (in fact, it was written by Abū Bakr Yahyā Ibn Hudhayl) and one verse of the reply by Ibn al-Qūtiyya. There are also two verses by an unknown author (Ibn al-Nașībī, "Masmū' Halab", Bibliotheca Alexandrina MS 297.124, fol. 7v). Below Ibn Ḥizb Allāh’s verses, Abū Ḥafṣ 'Umar Ibn al-Nașībī wrote down a poetical exchange, recited to him by Muḥammad al-Ḥakamī, between a man and a judge of Loja. See Appendix II.

69 Ibn al-Nașībī, "Masmū' Ḥalab”, Bibliotheca Alexandrina MS 297.124, fol. 7v.

70 Ibn al-Nașībī, "Masmū' Ḥalab”, Bibliotheca Alexandrina MS 297.124, fol. 7v.

71 Sibț Ibn al-'Ajamī, Kunūz al-dhahab (1996), 1: 485-486. 
recognize and understand who Ibn Hiizb Allāh was and what his life and position in Maghrib, as described in the Thabat, really meant. It should also not be forgotten that Muhammad al-Hakamī was born in a town not far from the birthplace of Ibn Hizb Allāh and this certainly had to have invoked curious feelings from encountering someone from his native land. ${ }^{72}$

Other Mamlūk scholars browsed the Thabat and studied Ibn Hizb Allāh's fragment but without any Andalusi or Maghribi scholars being present. One who left traces of this use was the well-known scholar, Ibn Ḥajar al-'Asqalānī (773852 H/1372-1449 CE) who stayed in Aleppo in Ramaḍān and Dhū al-Ḥijja 836 (Apr.-May and July-Aug. 1433) while accompanying sultan al-Ashraf Barsbāy (r. 825-841 H/1422-1437 CE) on his northern campaign. ${ }^{73}$ Sibt Ibn al-'Ajamī allowed him to copy from his Thabat and the entry on Ibn Hiizb Allāh in al-Durar al-kāmina is proof that Ibn Ḥajar read Ibn Ḥizb Allāh's holograph. ${ }^{74}$ The biographical sketch is composed of a shortened version of Ibn Ḥizb Allāh's biography, taken from Ibn al-Khațīb's Egyptian copy of al-Iḥāta fi ta'rīkh Gharnāta, which ends at the point Ibn Hizb Allāh leaves service in the Marīnid chancery, and the data taken from Thabat. ${ }^{75}$ Ibn Hajar's "addenda” says that Ibn Ḥizb Allāh traveled to the Mashriq, performed the pilgrimage, visited Jerusalem, and established himself there. He then adds that Sibt Ibn al-'Ajamī met him and transmitted his work in verse and prose. ${ }^{76}$ While in previous cases the Andalusi/Maghribi context was added by a scholar visiting Aleppo, Ibn al-Khațīb’s Ihāta served the same purpose and helped Ibn Ḥajar understand who Ibn Ḥizb Allāh was.

This can be corroborated by a second biographical sketch that Ibn Hajar included in his chronicle Inba a' al-ghumr. Radically differing from the first, this illustrates how a Mamlūk author could understand an Andalusi scholar without

72 In the 15th century, members of Hiizb Allāh family still lived in Wādī Āsh (Guadix). Archivo Histórico de la Nobleza, Cenete, box 330, doc. 14, 15 and 16; Osuna, box 1890, doc. 3, fol. 11v.

73 See al-Sakhāwī, al-Jawāhir (1999), 183-190. Another Mamlūk author who worked extensively with the Thabat was Ibn Fahd al-Makkī but he did not mention Ibn Hiizb Allāh in any of his surviving works. See al-Sakhāwī, al-Ḍaw' (1992), 1: 140; see also Ibn Fahd, Mu'jam al-shuyūkh (1982), 48; Ibn Ṭūlūn, “Kitāb al-arba'īn 'an arba īn shaykh”, Damascus Asad Library MS 958, fol. 22v. In 838 H/1434-5 CE, he left a reading note in Thabat. See Sibt Ibn al-'Ajamī, “Thabat”, AUB MS:297.124:S941tA, 2.

74 For instance, he mentioned in Ibn Hajar, al-Durar (1993), 1: 127-128 that he copied a poem written in the handwriting of Sibț Ibn al-'Ajamī. This is found in Sibt Ibn al-'Ajamī, "Thabat”, AUB MS:297.124:S941tA, 177-178. See also al-Sakhāwī, al-Ḍaw' (1992), 1: 143.

75 For the presence of Ibn al-Khațīb in the Mashriq see Castro León (in press).

76 Ibn Ḥajar, al-Durar (1993), 4: 200. 
having access to any source produced by him, or anyone that had actual experience of Western reality. The source for this second biography was the former chief Shāfi'ī judge, Burhān al-Dīn Ibn Jamā'a (725-790 H/1324-5-1388 CE), who became acquainted with Ibn Hiizb Allāh in Damascus. Later, Ibn Hiizb Allāh dedicated a work called 'Arf al-țîb fi wașf al-khațīb to him ("A fragrant perfume about the description of the khați b"). ${ }^{77}$ Whether Ibn Hajar knew this work or based his own work only on notes is not clear. However, he adds a verse from a qașida not found in any other source. It is very likely that Ibn Hajar accessed this information through some of the manuscripts belonging to the famous library of Burhān alDīn Ibn Jamā'a, which was accessible thanks to Mạ̣mūd al-Ustādār (d. 799 H/ 1396 CE), the majordomo of Sultān Barqūq, who bought and endowed it to his funerary madrasa. ${ }^{78}$ Burhān al-Dīn Ibn Jamā'a considered Ibn Ḥizb Allāh to be an excellent $k \bar{a} t i b$ and ordinary poet who authored a number of works on the religious merits of specific individuals. ${ }^{79}$ It is also striking that the only nisba of Ibn Hiizb Allāh mentioned in the biography is al-Maghribī. Clearly, this points to the perception of the group's cultural identity from a Mamlūk author's perspective.

This third-hand understanding of Ibn Hizb Allāh is also attested in al'Ulaymì's (860-928 H/1456-1522 CE) chronicle of Jerusalem. ${ }^{80}$ He included Ibn Hiizb Allāh in the section on the Mālikī judges of Jerusalem after he came across notary documents verified by him in Safar 781/May-June $1379 .{ }^{81}$ Only the word 'allāma suggests that he had any idea of Ibn Hizb Allāh's skills and knowledge as only two other Mālikīs are introduced using the same honorific title. ${ }^{82}$ Unlike in the cases of other Mālikī scholars mentioned in that chapter, al-'Ulaymī omits his Western origins (al-Maghribī) giving him another nisba, al-Mālikī, applied frequently to Maghribi scholars by Mamlūk authors.

Indeed, the evidence of al-'Ulaymī and Ibn Hajar's Inbā' al-ghumr indicates how difficult it was to interpret a Mamlūk-Andalusi scholar without having access to Ibn Hizb Allāh's holograph. On the other hand, the existence of Sibṭ Ibn

77 My thanks go to Teresa Garulo for helping me to understand the correct rhyme in the title of this work.

78 Behrens Abouseif 2019, 25. The story is mentioned by Ibn Ḥajar in the obituary of Burhān alDīn Ibn Jamā'a. See Ibn Ḥajar, Inbā’ al-ghumr (1972), 1: 355.

79 Ibn Ḥajar, Inbā' al-ghumr (1972), 1: 328.

80 Al-'Ulaymī, al-Uns (1999), 2: 362-363.

81 Little 1995, 245.

82 The other two being a Mālikī chief judge of Jerusalem, Ibn 'Awjān (763-838 H/1361-21434 CE) and Yaḥyā al-Anșārī al-Andalusī (856-895 H/1451-2-1490 CE) who was of Andalusi origin and served as the Mālikī chief judge of the city (al-'Ulaymī, al-Uns [1999], 2: 366 and 374). 
al-'Ajamì's Thabat reveals not only the process of transmission, but also the further use of this material and confirms Ibn Hizb Allāh's intent to have it studied and copied by others in the future. One other example of this same approach is that of another Andalusi scholar, Abū 'Amr Muhammad Ibn al-Murābit (680752 H/1281-2-1351 CE), who lived in Damascus in the first half of the 8th/14th century. This son of kātib al-sirr (private chancellor) to the Nașrid sultan Muhammad II (r. 672-702 H/1273-1302 CE) became famous in Damascus for his teaching of Sunan al-Nasā' $\bar{l}$ and his ijāza granted in 743 H/1342 CE passed into the manuscript tradition of this work..$^{83}$ Likewise, the holograph sama' 'a al-Murābit's chain of transmission to this work was circulated in the Thabat of Ibn al-Fașīh al-Hamadhānī (d. 795 H/1392 CE), which was read by Ibn Ḥajar. ${ }^{84}$ Abū al-Hasan Ibn Maymūn al-Balawì's exceptionally long holograph ijāza circulated in Mamlūk territory but I have not found any evidence for it being copied or used for writing his biography by Mamlūk authors. ${ }^{85}$

\section{Conclusions}

Ibn Ḥizb Allāh's holograph ijāzas are not the only surviving Andalusi manuscripts created in Mamlūk territory. There are many others. However, it is the unique traceable creation and the history of use by their owner, Sibt Ibn al'Ajamī, which illuminates the different levels of understanding and reception of this one particular Andalusi scholar. Ibn Hiizb Allāh wanted to be known, and remembered, as a kātib with close ties to the "King of the Maghrib", the Marinid sultan Abū 'Inān Fāris. His friend, a much younger Andalusi scholar, Ibn Maymūn al-Balawī, helped him to adapt his image to be more comprehensible to Mamlūk scholars and, indeed, for Sibṭ Ibn al-'Ajamī himself. However, in the absence of the direct involvement of its two creators, and their familiarity with the

83 Al-Nasā'ì, Sunan al-kubrā (1991), 1: 61; al-Nasā'ī, Sunan al-kubrā (2001), 1: 64 and 67. Ibn alMurābit transmitted the work on the authority of Ibn al-Zubayr al-Thaqafí. Ibn al-Zubayr and his works were well known in Damascus. At least one other Andalusi scholar, Abū al-Qāsim Ibn Sahl, brought to the city his holograph ijāza. See al-Dhahabī, Tadhkira al-ḥuffāz (1955), 4: 1484. Abū 'Amr Muhammad Ibn al-Murābit authored several works that circulated in holograph manuscripts in the Mashriq. See Ibn Hajar, al-Durar (1993), 4: 45.

84 Ibn Ḥajar, Inbā' al-ghumr (1972), 1: 461 (biog. 'Abd al-Rahīm b. Aḥmad Ibn al-Fașīh). See also the biography of his son Ahmad (d. 828 H/1424 CE). Ibn Ḥajar, Inbä' al-ghumr (1972), 1: 352. Another student of Ibn al-Murābiṭ with whom Ibn Ḥajar studied was Ibn Kuwayk (737-821 H/13371418 CE). See Ibn Hajar, al-Majma (1994), 2: 477.

85 Dār al-Kutub MS majmū'a 135, fol. 98v. 
symbolic world of the profession of the Maghribi chancellors, this image inevitably changed with the passage of time and, as such, so, too, did the identity of Ibn Ḥizb Allāh.

Two later cases of the interpretation of Ibn Hizb Allāh demonstrate that after many years, in the absence of any first-hand personal contact, Ibn Hiizb Allāh's texts as an ego-document became incomprehensible to Mamlūk scholars. Exactly as Assmann pointed out, later readers were only able to reconstruct the text within their own contemporary frames of reference. ${ }^{86}$ While they had the skills to evaluate literary texts, they were ignorant of the role of a Maghribi kātib. On the other hand, Sibt Ibn al-'Ajamī used Ibn Ḥizb Allāh in the presence of other Western scholars. This distant connection between Ibn Hiizb Allāh's literary works collected in the past and other Maghribi scholars in the present revealed how a Mamlūk scholar could use texts to link himself to them. Although these scholars might have been unfamiliar with Ibn Hiizb Allāh, they were able to recognize his importance and his use of symbolic language at the court of Marīnid sultans.

Ibn Ḥajar and al-' 'Ulaymī were the only later biographers to mention Ibn Hiizb Allāh, and were unaware of who he was. He existed only as a name in texts they came upon. In the case of Ibn H̦ajar, the reading of an Andalusi biographical dictionary and browsing the ijāzas given to Sibț Ibn al-'Ajamī enabled him to recreate a biographical sketch of Ibn Hiizb Allāh. However, after one studies it, it is hard to recognize in its depiction an important kātib. It is a very different Ibn Hizb Allāh who is being presented here. In this regard, the holograph manuscript illustrates how our understanding of Ibn Hiizb Allāh's presence in the Mashriq could be more elaborated, or change completely, if we use this type of material. It also shows the simplistic interpretations of his life in the East that would result if researchers based themselves only on the available material produced by Mamlūk scholars. However, no generalization should be based on one isolated case, even if it is as detailed as Ibn Ḥizb Allāh's. Other manuscripts can clarify details about those who produced them, even if very few are accompanied by details relating to their history.

Finally, Ibn Hiizb Allāh's manuscript is one of very few texts where an Andalusi scholar mentioned his ties and contacts with other Andalusi scholars living in Mamlūk lands. ${ }^{87}$ The relationship between Andalusis is, for Ibn Ḥizb Allāh, also attested to by Ibn al-Khatiib in Fez, who knew that his former colleague and friend was living quietly in the East. Ibn al-Khatịb articulated this information in his final biographical dictionary when he sought to follow a similar path, to save

86 Assmann/Czaplicka 1995, 130.

87 In this case, Ibn Maymūn al-Balawī. 
his life by fleeing East. Could Ibn Hizb Allāh have set the example for future Maghribi exiles such as Ibn Marzūq and Ibn Khaldūn, and could he have been the one to have shown them that it was possible to distance themselves from the dangerous political situations they faced and, instead, be able to live peacefully in the Mashriq? Regardless of whether a conclusive answer is possible or not, the question itself is evidence of the importance of the study of the manuscripts of Mamlūk-Andalusis.

\section{Appendix I: Edition of Ibn Ḥizb Allāh's ijāzas}

The current order of the three ijāzas in the manuscript, including the fragment of Rihla, reflects Sibț Ibn al-'Ajamī's thematic approach towards the texts. I reordered them in chronological order as they were produced by Ibn Ḥizb Allāh and Ibn Maymūn al-Balawī. I have adapted the text to some modern standard Arabic ortographic conventions, adding dots, and medial and final hamzas, when necessary. The edition follows the use of the vocalization marks and initial hamza by Ibn Hiizb Allāh and Ibn Maymūn al-Balawī as much as possible. ${ }^{88}$

\section{Ijāza given by Ibn Ḥizb Allāh to Sibṭ Ibn al-'Ajamī, 4 Sha'bān 784/13 October 1382 (Sibṭ Ibn al-'Ajamī, "Thabat”, AUB MS:297.124:S941tA, 570-573)}

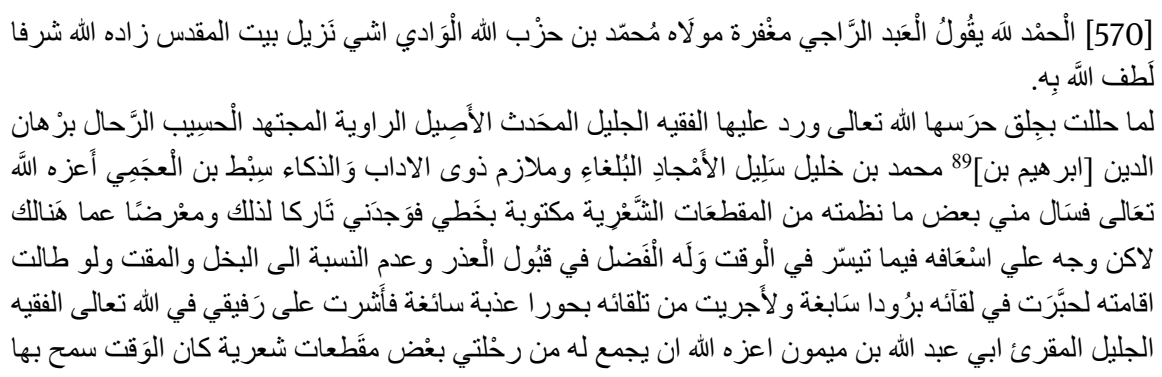

88 My thanks to Luis Molina for helping me to fully understand Ibn Ḥizb Allāh’s language and his figurative forms of expression.

89 The words in brackets are inserted above the words "al-Dīn Muhammad b. Khalill" and with a different, thicker, pen. 
ارتجالا في كو ائن شتى. منها ما قلته حِين تركت ملك المغْرب قدس الله روحه ابا عنان ببلاد الجريد وفَررت من

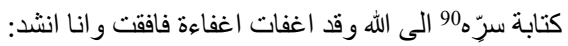

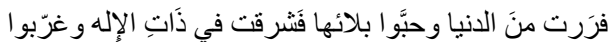

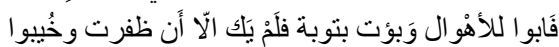

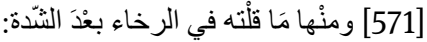

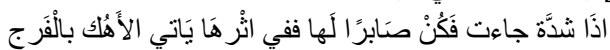

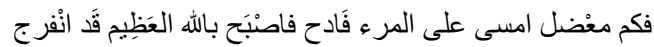

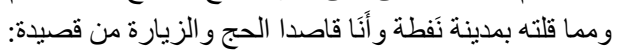

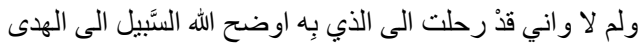

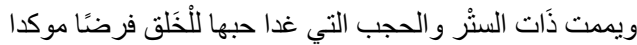

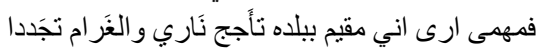

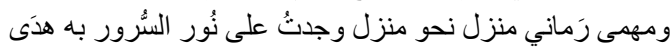

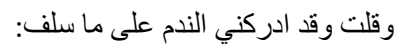

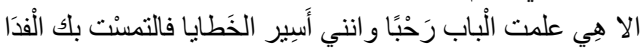

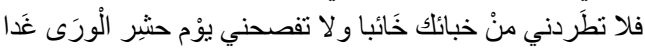

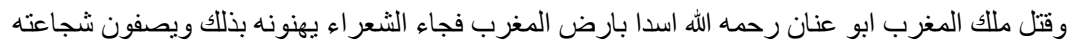

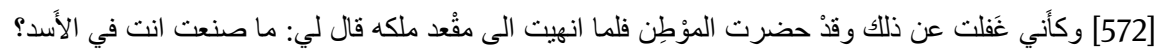

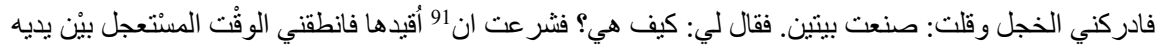
فقلت في الفور: الفي الفي

ايا ليث الملوك صر عُت ليثا تصندى في طريقلك للجيُوش

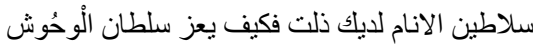

فنشكر بها.

وفي حضرته ارتجل بعض الكتابِ و هو ابو عبد الله العزفي عند الفجر ابْيَتاتا يصف انفصال الليل و اقُبال النهار فَقَال:

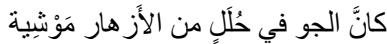

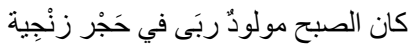

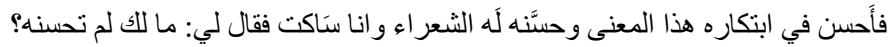

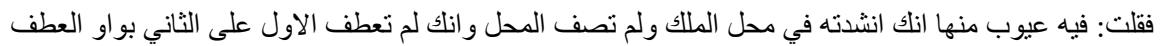

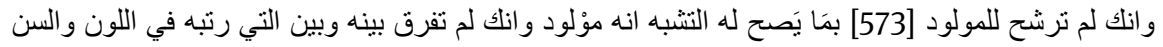

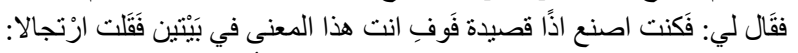

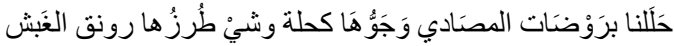

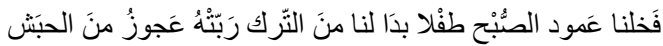
فسر الجميع بذَللك فَانقطع.

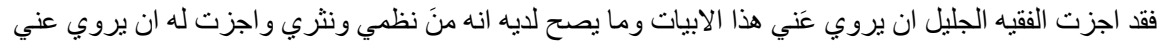

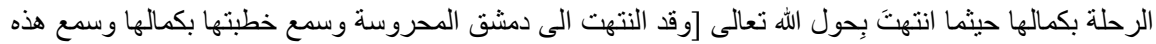

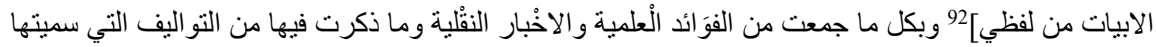

90 Tashdìd written with a different, thicker, pen.

91 After the word ان, Ibn Ḥizb Allāh crossed out another

92 Written in the right margin with a different, thicker, pen. 
على شتى أَنواعِهَا واخْتلاف فنونها اجازة صحيحة على الثرط المعروف و المنحَى المالوف و الله تعالى يُوفقه

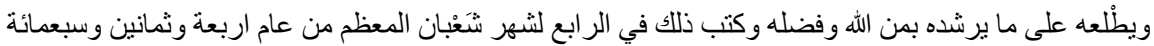

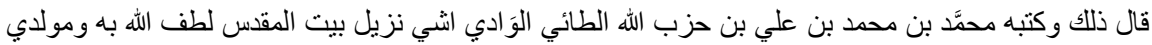

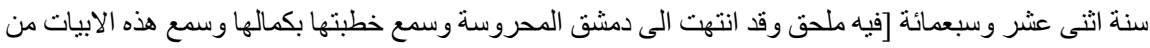
لفظي فيه مصلح في الصيغة السر ان وفي التاريخ المذكور].

\section{The Chapter on Cairo from Ibn Hizb Allāh's Riḥla entitled al- Rawḍa al-arị̣a al-ḥizbiyya wa-l-rihla al-gharbiyya al-gharība wa-tatlūhā al-hijāziyya wa-l-shāmiyya by Ibn Ḥizb Allāh with an ijāza dated on 5 Sha 'bān 784/14 October 1382 (Sibṭ Ibn al- 'Ajamī, “Thabat”, AUB MS:297.124:S941tA, 568-569)}

[568]

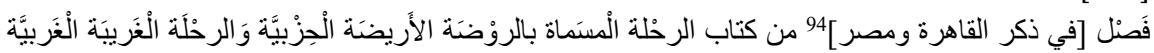

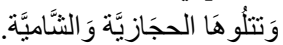

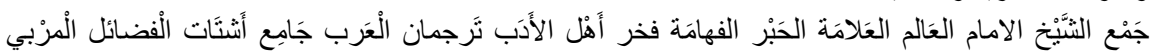

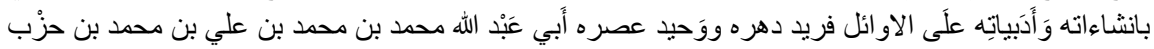

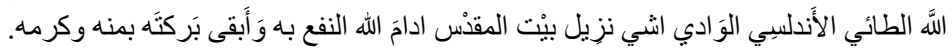

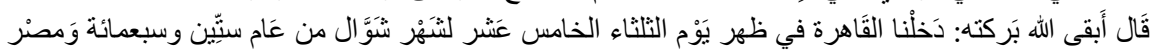

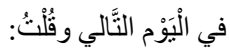

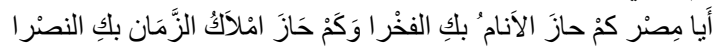

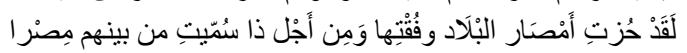

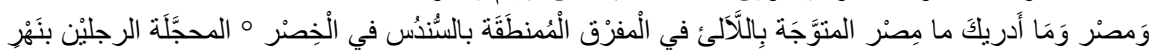

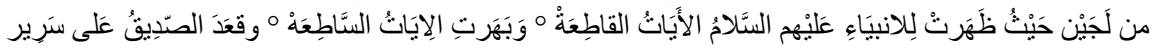

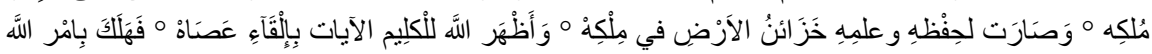

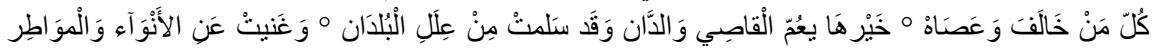

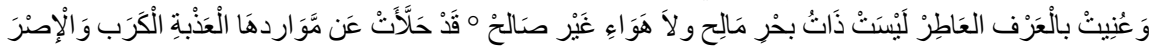

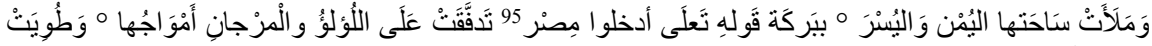

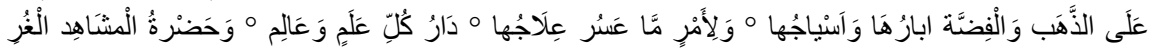

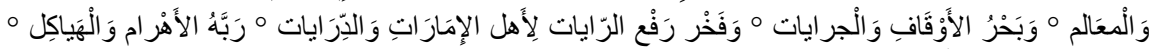

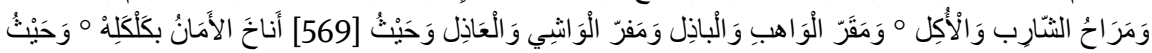

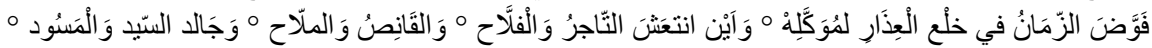

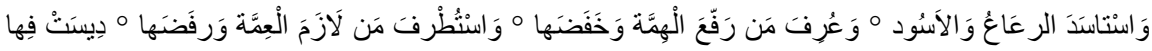

93 Written above the word فَصنْ

94 Inserted above the words من كتاب الرحُلة

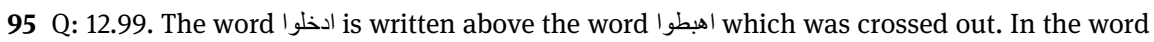
oصنُر the final alif was crossed out. The original verse was from Q: 2.61. 


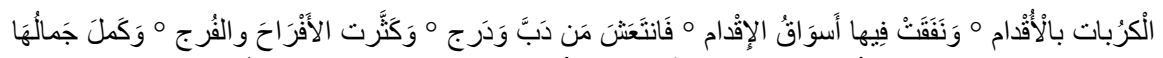

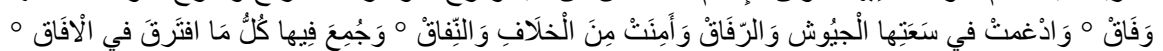

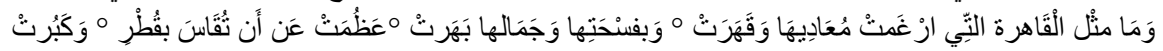

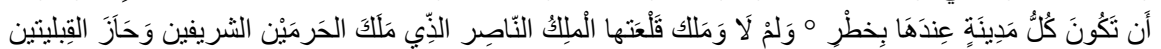

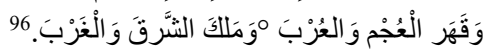

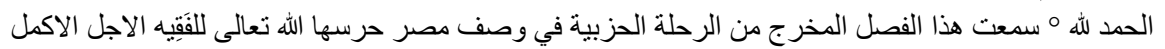

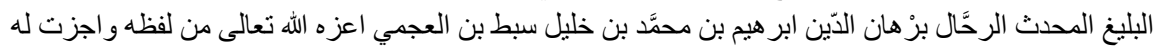

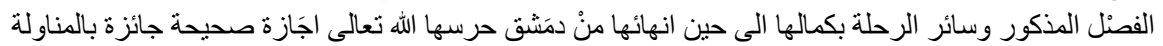

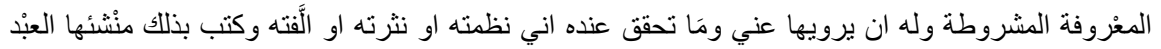

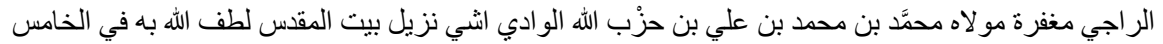
لثهر شعبان المكرم من عام اربعة وثمانين وسبعمانة.

\section{3. ljāza given by lbn Ḥizb Allāh to Abū al-Ḥasan 'Alī lbn Bahrām al-Ḥalabī, dated 6 Sha'bān 784/15 October 1382 (Sibṭ Ibn al-'Ajamī, "Thabat”, AUB MS:297.124:S941tA, 574)}

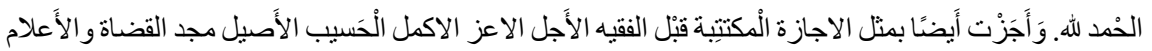

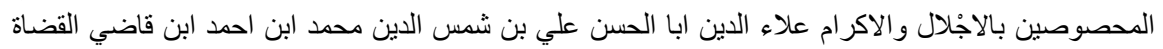

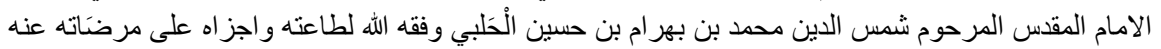

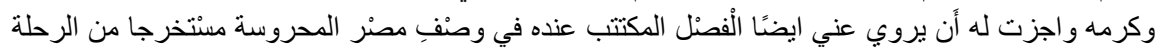

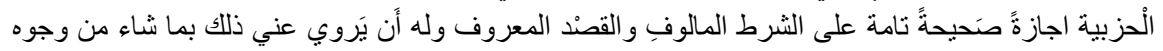

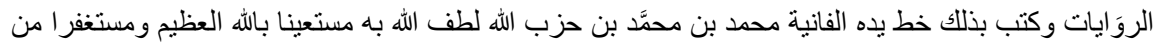

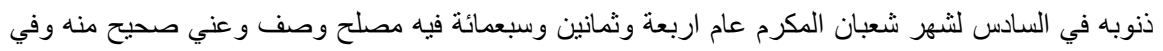
التاريخ.

96 The end of the handwriting of Ibn Maymūn al-Balawī. 


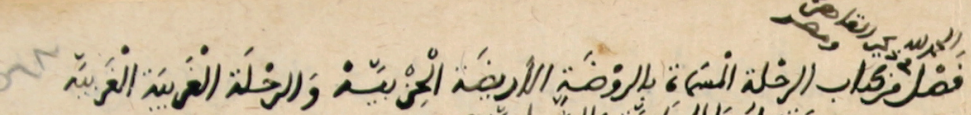

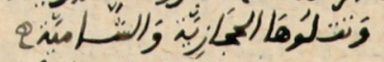

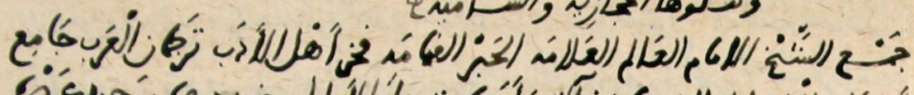

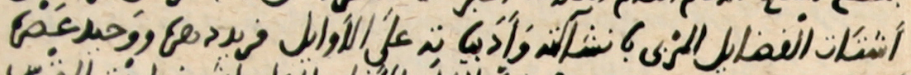

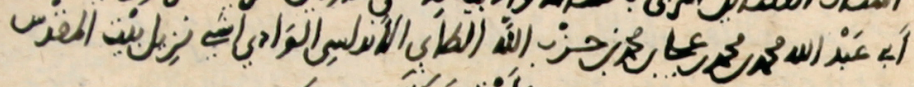

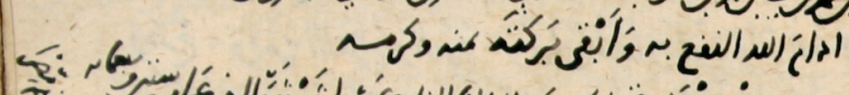

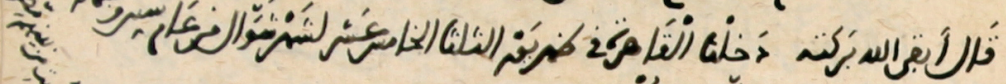
(h)

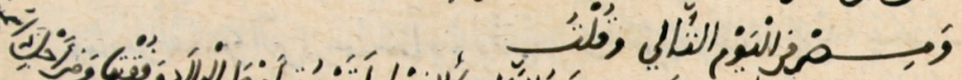

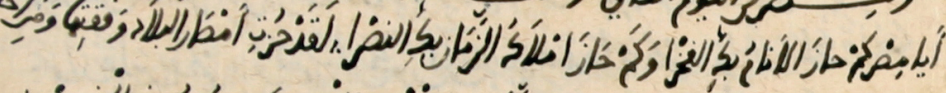

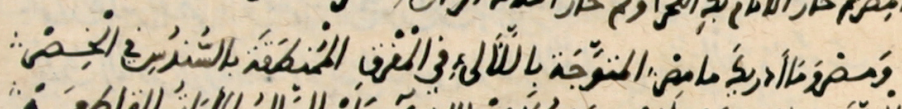

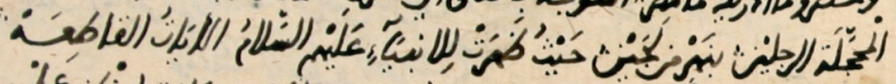

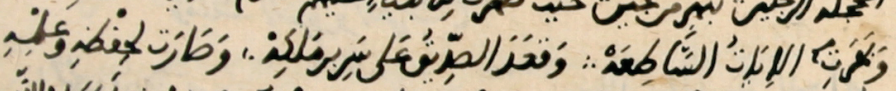

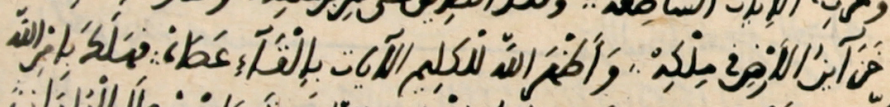

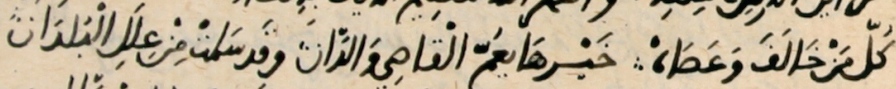

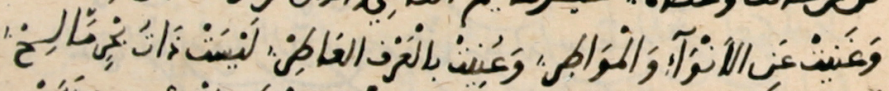

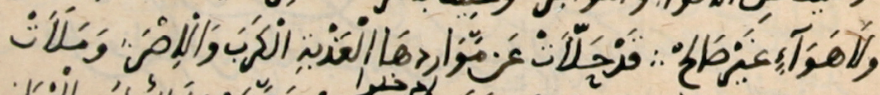

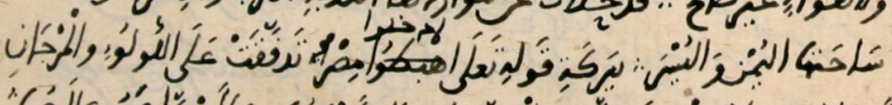

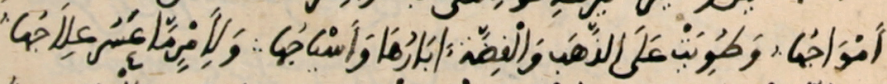

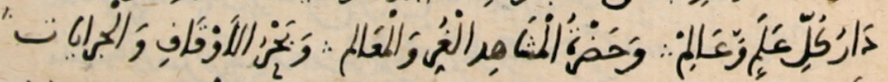

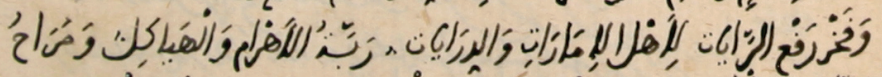

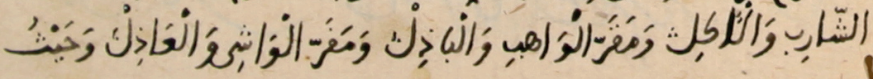

Fig. 1: Sibṭ Ibn al-‘Ajamī, “Thabat”, AUB MS:297.124:S941tA, 568 


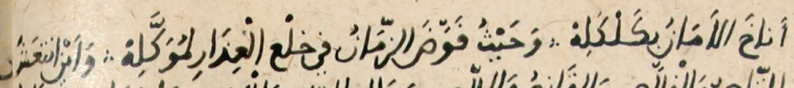

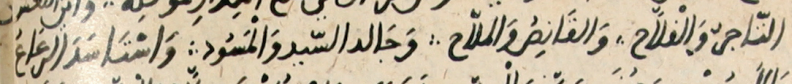

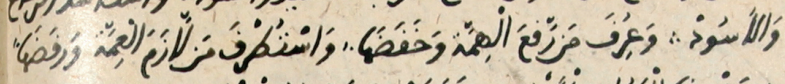

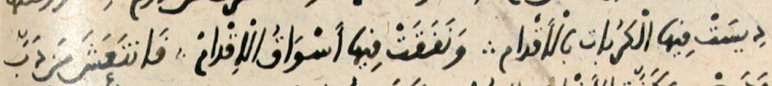

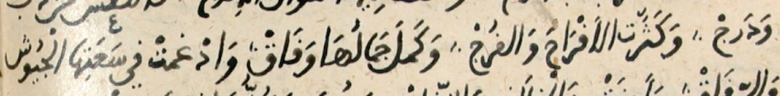

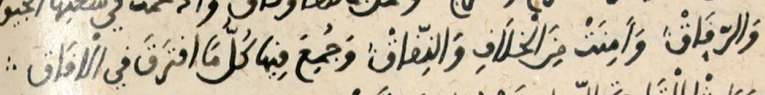

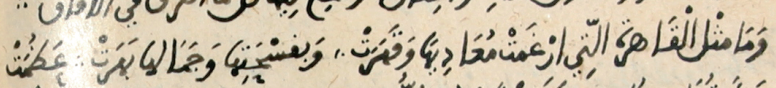

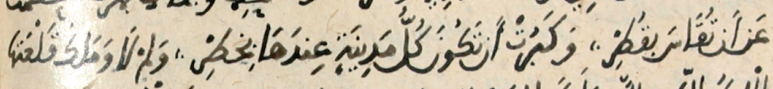

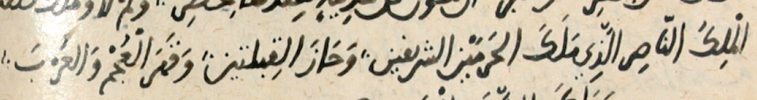

$$
\text { Q }
$$

$\rightarrow$ त्र

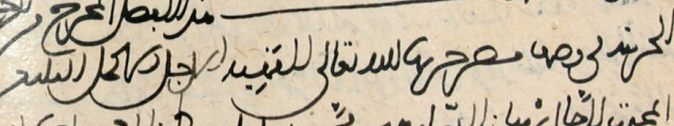

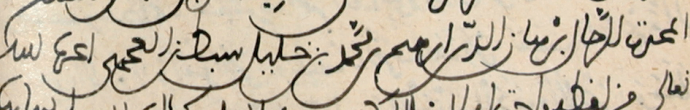

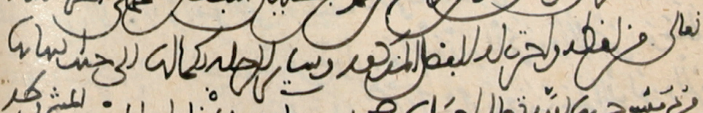

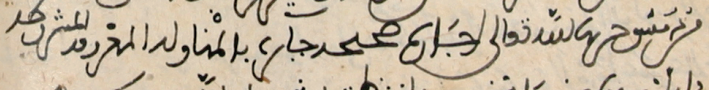
ow, $i$, sinf

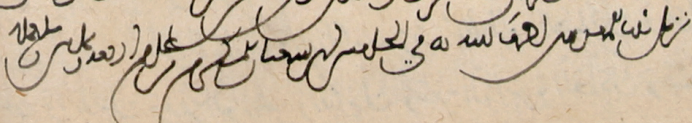

נر

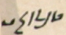
(גועד

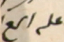
N

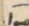

ier ses

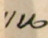
by

11

Fig. 2: Sibṭ Ibn al-'Ajamī, “Thabat”, AUB MS:297.124:S941tA, 569 


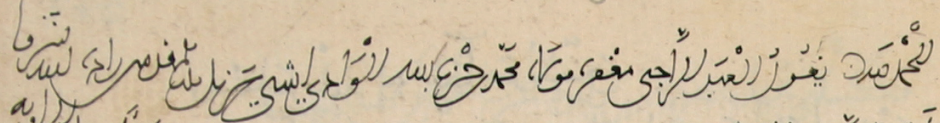

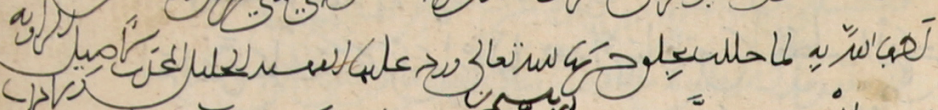
كrill

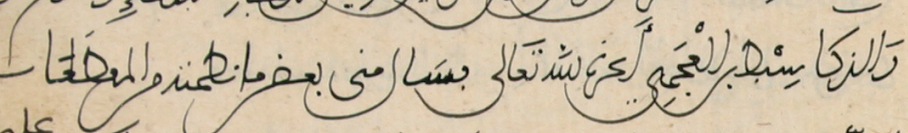

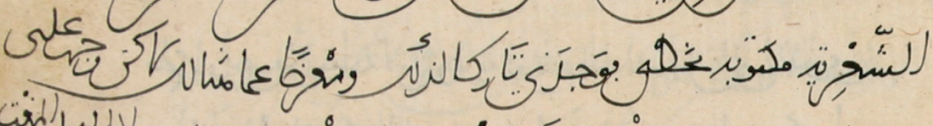

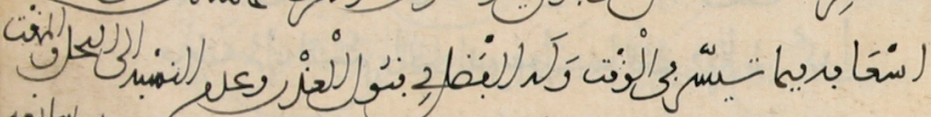
inlu

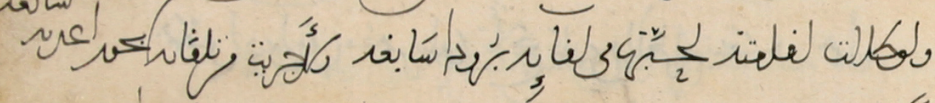

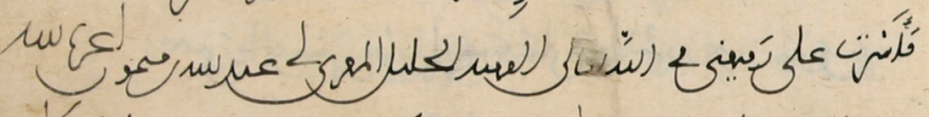

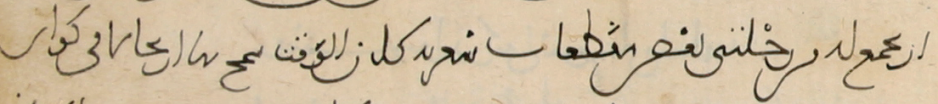

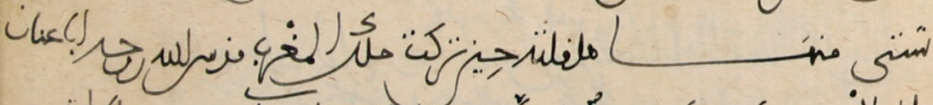

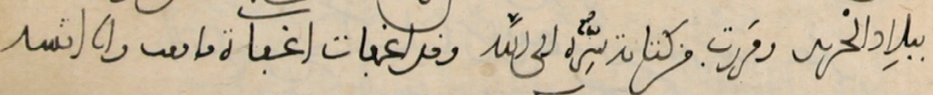

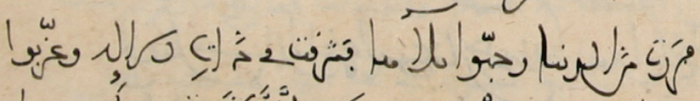

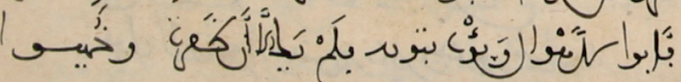

Fig. 3: Sibṭ Ibn al-'Ajamī, “Thabat”, AUB MS:297.124:S941tA, 570 


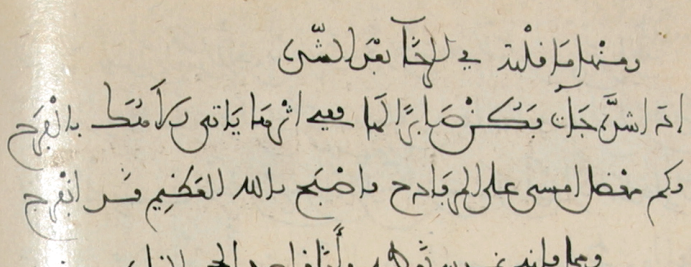

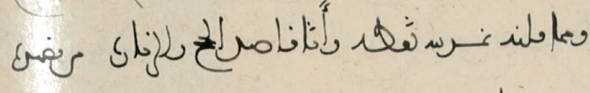

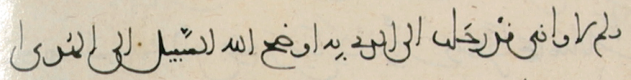

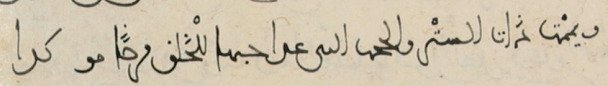

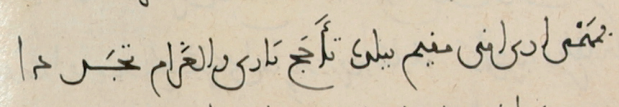

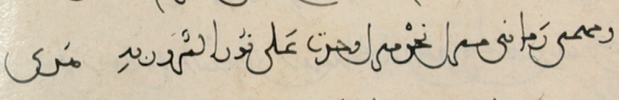
دod

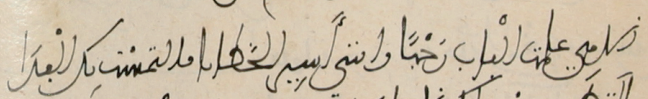

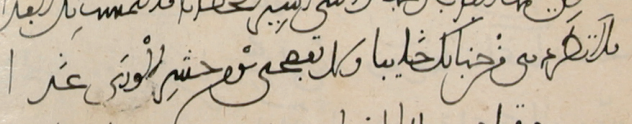
sich

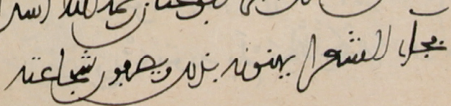

Fig. 4: Sibț Ibn al-'Ajamī, "Thabat”, AUB MS:297.124:S941tA, 571 


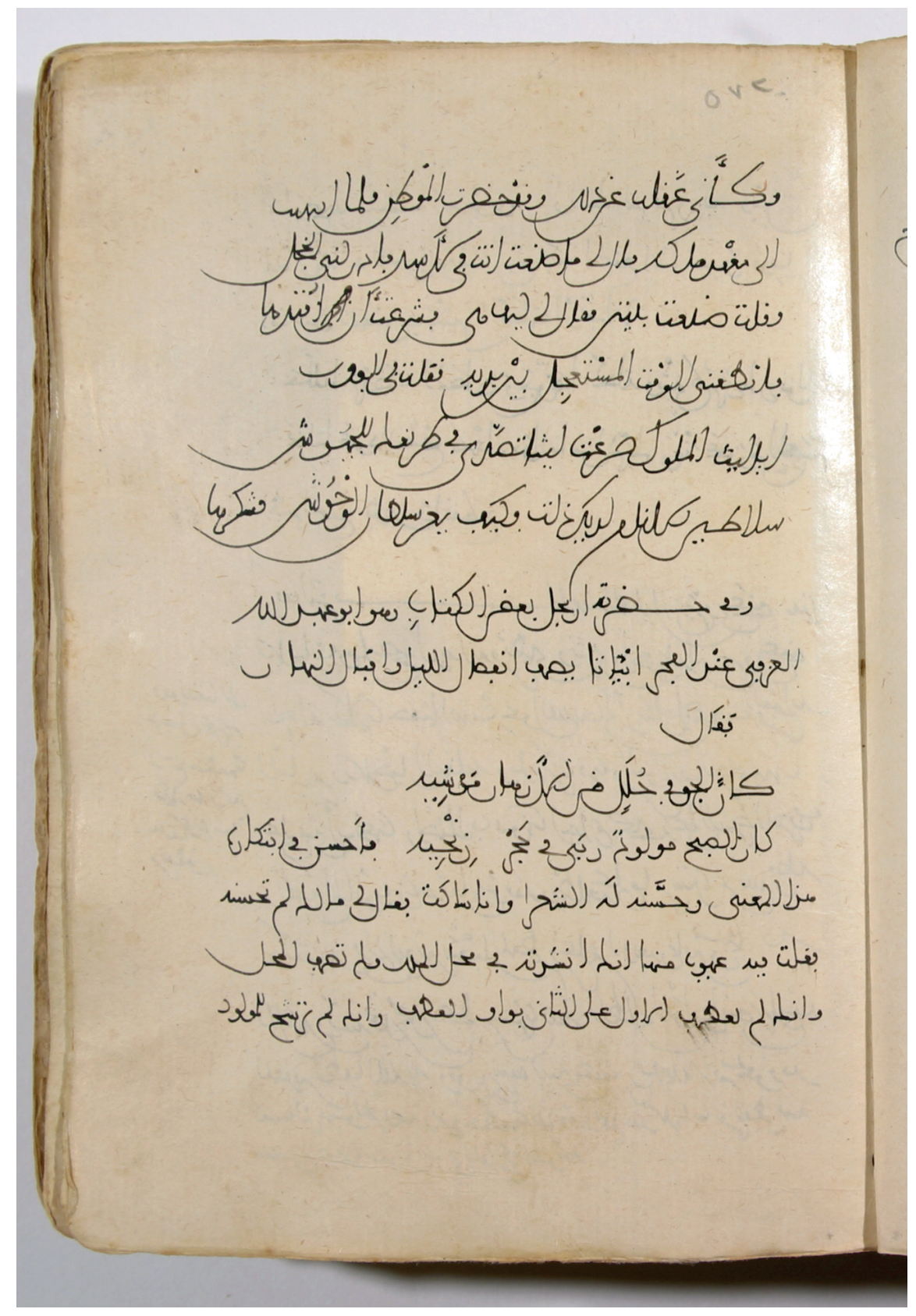

Fig. 5: Sibṭ Ibn al-'Ajamī, “Thabat”, AUB MS:297.124:S941tA, 572 


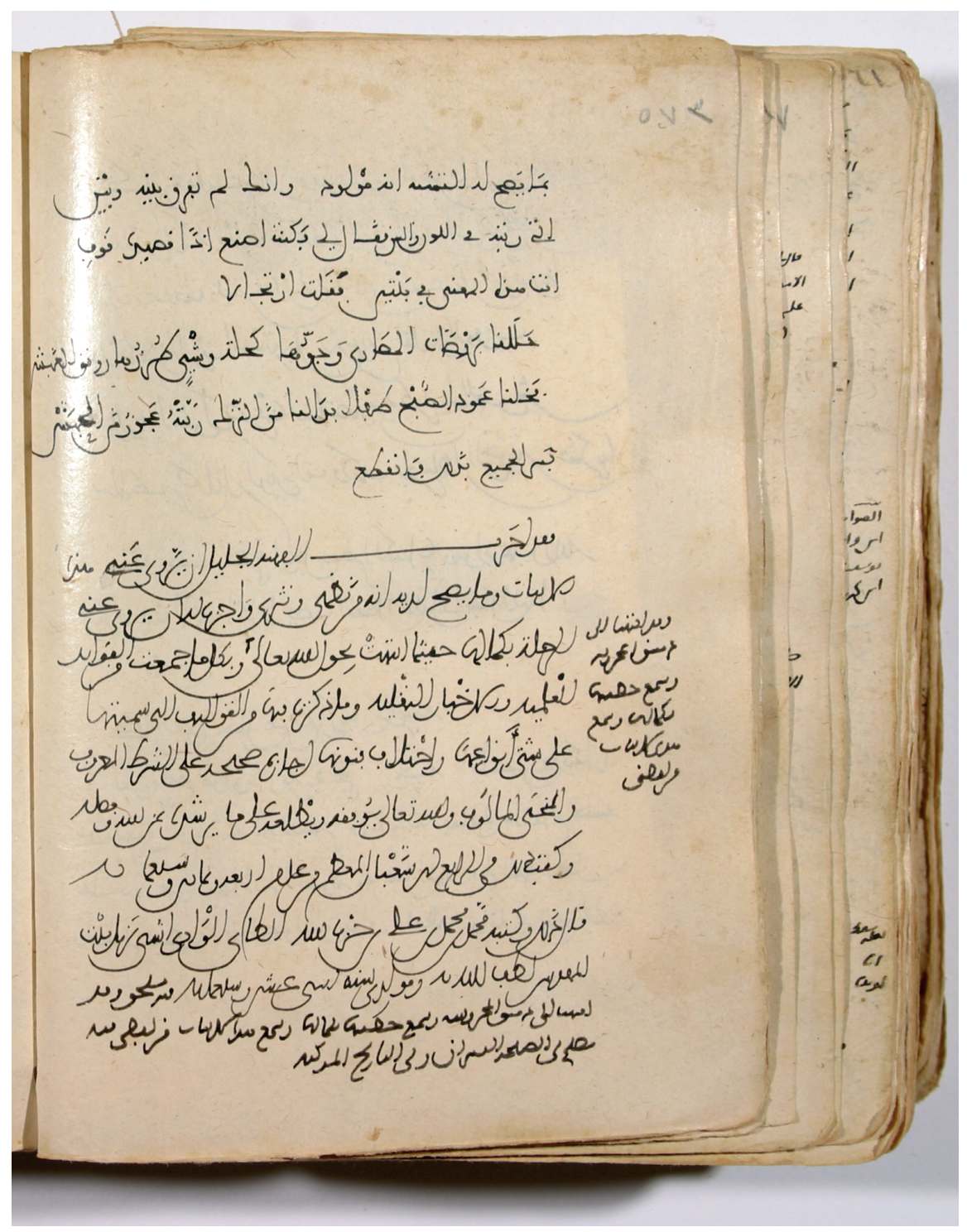

Fig. 6: Sibṭ Ibn al-'Ajamī, “Thabat”, AUB MS:297.124:S941tA, 573 


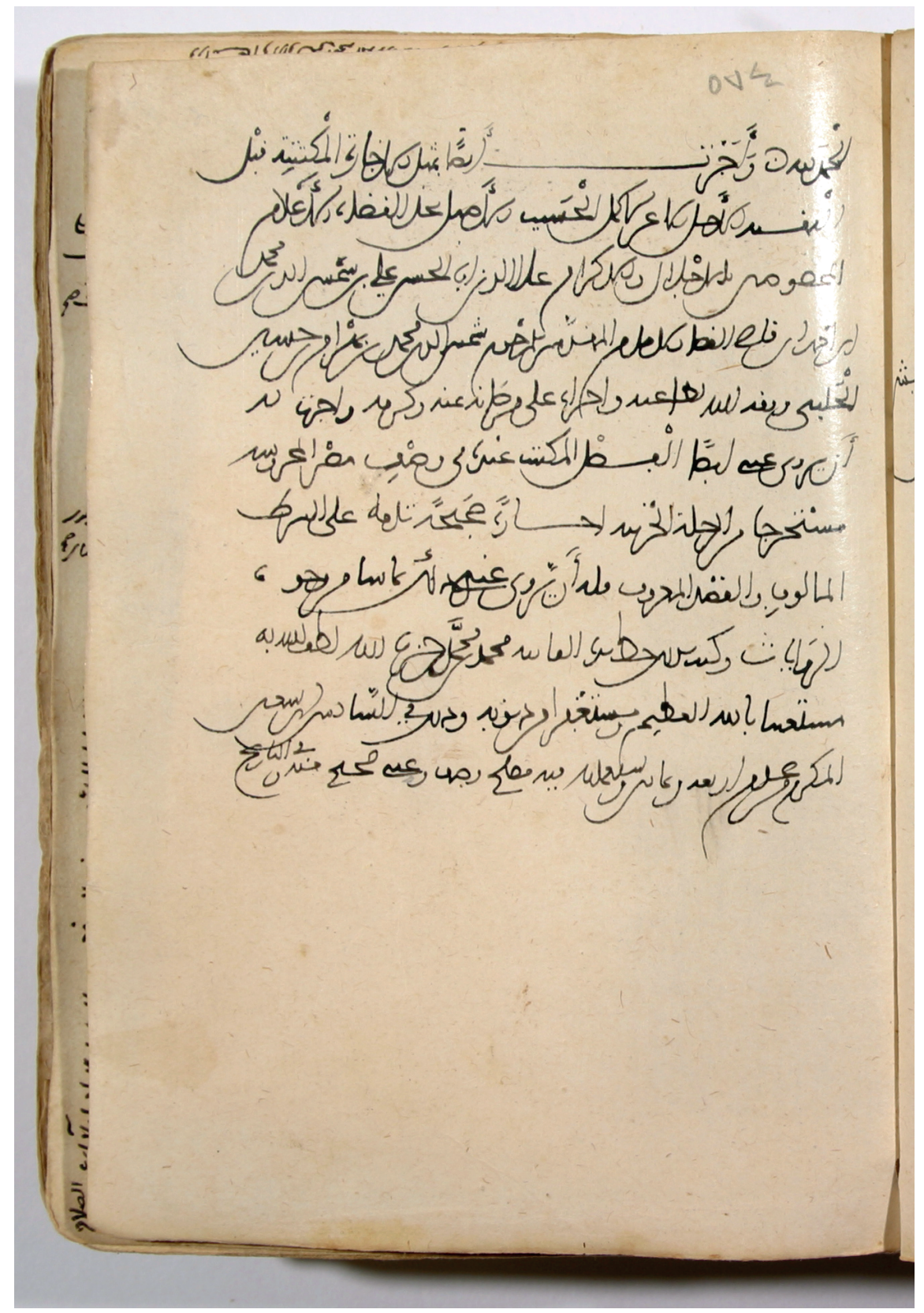

Fig. 7: Sibṭ Ibn al-'Ajamī, “Thabat”, AUB MS:297.124:S941tA, 574 


\section{Appendix II: Edition of Ibn Ḥizb Allāh’s poetry}

Ibn al-Nașībī, “Masmū' Ḥalab”, Bibliotheca Alexandrina MS 297.124 (olim 2115d), fols. $7 \mathrm{v}$ and 8r. The poetry recited by Sibț Ibn al- 'Ajamī and al-Hakamī in Dhū alQa'da 839/May-June 1436. Since Ibn al-Nașībī always starts with the hamdala, the poems in fol. $8 \mathrm{r}$ precedes the ones in fol. $7 \mathrm{v}$. The edition follows the use of the vocalization marks by Ibn al-Nașībī.

$8 \mathrm{r}$

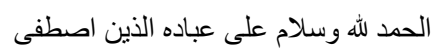

و انشدنا الثيخ ابر هيم المذكور قال انثدنا الثيخ شمس الدين [محمد بن محمد بن علي]97 بن حزب الله الو ادياشي]!]

ايا ليث الملوك صر عت ليثا تصدى في طريقلك للجيوش

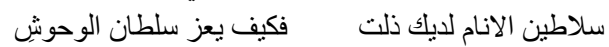

وذللك يوم الجمعة ثامن شهر ذي القعدة الحر ام سنة 839.

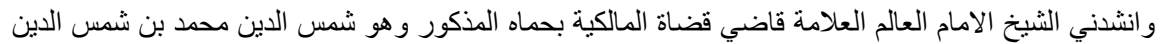

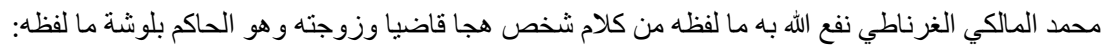

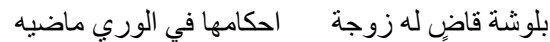

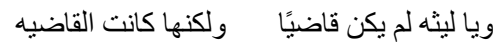

فكتب اليه جواب البيتين:

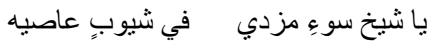

كلا لئن لم تنته

$7 \mathrm{v}$

$$
\begin{aligned}
& \text { و انشدني الثيخ شمس الدين المالكي الغرناطي من لفظه و هو لابي علي القالي يخاطب به ابن القوطية: }
\end{aligned}
$$

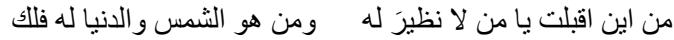

$$
\begin{aligned}
& \text { واجابه بن القُوطيه من ساعته: }
\end{aligned}
$$

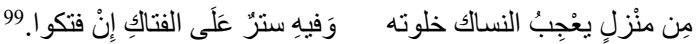

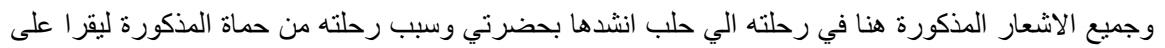

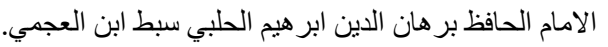

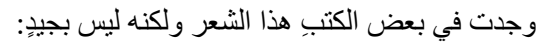

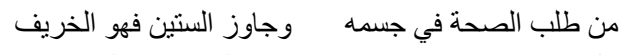

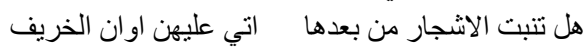

97 صح . Inserted above the word al-din.

98 Al-Maqqarī, Nafḥ al-țīb (1988), 4: 294. Al-Maqqarī offers a slightly different version.

99 Al-Maqqarī, Nafḥ al-țīb (1988), 3: 74; Ibn Khallikān, Wafayāt al-a yōān (1994), 4: 369. Again, it differs from the one recited by al-Ḥakamī. 


\section{Bibliography}

\section{Manuscripts}

Al-Basțī al-Fihrī, "Zahrat al-ādāb wa-tuḥfat ūlā al-albāb”, Bibliotheca Alexandrina MS 892.7 (olim ādāb 76).

Al-Bishtakī, “Markaz al-Iḥāta bi-udabā' Gharnāța”, Bibliothèque Nationale de France Arabe 3347.

Ibn Khațīb al-Nāṣiriyya, “Al-Durr al-muntakhab bi-takmilat ta'rīkh Ḥalab”, Bibliothèque Nationale de France Arabe 2139.

Ibn Maymūn al-Balawī, “ljāza”, Dār al-Kutub wa-l-wathā’iq al-qawmiyya al-mișriyya MS majmū'a 135, fols. 94r-103v.

Ibn al-Nașībī, “Masmūc Ḥalab”, Bibliotheca Alexandrina MS 297.124 (olim 2115d).

Ibn al-Shị̣na, “Thabat”, Jāmi'at al-imām Muḥammad b. Sa'ūd al-Islāmiyya MS 7235.

Ibn Ṭūlūn, "Kitāb al-arba'īn 'an arba'īn shaykh”, Damascus Asad Library MS 958.

Ibn Zurayq, “Tarājim Shuyūkh Dimashq”, Princeton Garrett MS 178B.

Muhammad al-Salāmī, "Thabat”, Universitätsbibliothek Leipzig MS Vollers 721.

Sibṭ Ibn al-'Ajamī al-Ḥalabī, Burhān al-Dīn, “Thabat”, American University of Beirut, MS:297.124:S941tA.

Staatsbibliothek zu Berlin Mq. 123, fols. 76r-81v.

\section{Archival documents}

Archivo Histórico de la Nobleza, Cenete, box 330, doc. 14, 15 and 16.

Archivo Histórico de la Nobleza, Osuna, box 1890, doc. 3.

\section{Primary Sources}

Arberry, A. J. (1996), The Koran Interpreted. A Translation, New York: Touchstone.

Al-Biqā'ī, Ibrāhīm (2010), 'Unwān al-'Unwān aw al-mu'jam al-ṣaghīr, ed. by Ḥasan Ḥabshā, Cairo: Mațba'at Dār al-Kutub wa-l-Wathā'iq al-Qawmiyya.

Al-Burayhī, 'Abd al-Wahhāb (1994), Ṭabaqāt șulahāa' al-Yaman al-ma'rūf bi-Ta'rīkh al-Burayhī, ed. by 'Abd Allāh Muḥammad ب̣ibshī, Sanaa.

Al-Dhahabī, Shams al-Dīn Muḥammad (1955), Tadhkirat al-ḥuffāze, ed. n.n., 4 vols., Hyderabad: Dā'irat al-Ma'ārif al-'Uthmāniyya.

Ibn al-Aḥmar, Abū al-Walīd Ismā'īl (1987), Nathīr al-jumān fĩ shír man naẓamanī wa-iyyāhu alzamān, ed. by Muḥammad Rị̣wān al-Dāya, Beirut: Mu'assasat al-Risāla.

Ibn Fahd al-Makkī, Muḥammad b. 'Umar (1982), Mu'jam al-shuyūkh, ed. by Muhammad al-Zāhī, Riyadh: Manshūrāt Dār al-Yamāma li-l-Baḥth wa-l-Tarjama wa-l-Nashr.

Ibn Ḥajar al-'Asqalānī, Shihāb al-Dīn Aḥmad (1992), Dhayl al-Durar al-Kāmina, ed. by 'Adnān Darwīsh, Cairo: Ma'had al-Makhțūțāt al-'Arabiyya.

Ibn Ḥajar al-'Asqalānī, Shihāb al-Dīn Aḥmad (1993), al-Durar al-kāmina fĩ a'yān al-mi’a althāmina, 4 vols., Beirut: Dār al-Jīl. 
Ibn Ḥajar al-'Asqalānī, Shihāb al-Dīn Ạ̣mad (1972), Inbā' al-ghumr bi-anbā' al-'umr, ed. by Ḥasan Ḥabshī, Cairo: Lajnat Iṇyā' al-Turāth al-Islāmī.

Ibn Ḥajar al-'Asqalānī, Shihāb al-Dīn Aḥmad (1994), al-Majma' al-mu'assis li-l-mu'jam al-mufahris, ed. by Yūsuf 'Abd al-Raḥmān al-Mar'ashlī, Beirut: Dār al-Ma'ārifa.

Ibn al-Ḥājj al-Numayrī (1990), Fay ạ al-ubāb wa-ifādat qidāḥ al-ādāo fí al-ḥaraka al-saīida ilā Qusanțina wa-l-Zāb, ed. by Muḥammad Ibn Shaqrūn, Beirut: Dār al-Gharb al-Islāmī.

Ibn Ḥijjī, Shihāb al-Dīn Aḥmad (2003), Ta’rīkh Ibn Hiijjī, ed. by Abū Yaḥyā 'Abd Allāh al-Kandarī, Beirut: Dār Ibn Ḥazm.

Ibn al-Jazarī, Muḥammad (1933), Kitāb Ghāyat al-nihāya fi țabaqāt al-qurrā', ed. by Gotthelf

Bergsträsser and Otto Pretzl, 3 vols., Cairo: Maṭba'at al-Sa'āda li-Jam iyyat al-

Mustashriqīn al-Almāniyya.

Ibn Juzayy, 'Abd Allāh (1986), Kitāb al-Khayl Mațla' al-Yumn wa-l-iqbāl fí intiqā' kitāb al-ị̣tifāl, ed. by Muḥammad al-'Arabī al-Khațțābī, Beirut: Dār al-Gharb al-Islāmī.

Ibn Khalīl, 'Abd al-Bāsiṭ (2002), Nayl al-amal fi dhayl al-duwal, ed. by 'Umar 'Abd al-Salām Tadmurī, 9 vols., Șaydā - Beirut: al-Maktaba al-Așriyya.

Ibn Khallikān, Aḥmad (1994), Wafayāt al-a'yān wa-anbā' abnā̄' al-zamān, ed. by lḥsan 'Abbās, 8 vols, Beirut: Dār Șādir.

Ibn al-Khațīb, Lisān al-Dīn (2002), Awșāf al-nās fi tawārīkh wa-l-ṣalāt, ed. by Muḥammad Kammāl Shabbāna, Cairo: Maktabat al-Thaqāfa al-Dīniyya.

Ibn al-Khațīb, Lisān al-Dīn (2001), al-Iḥāta fi akhbār Gharnāṭa, ed. by Muḥammad 'Abd Allāh 'Inān, Cairo: Maktabat al-Khānjī (4th edition).

Ibn al-Khațīb, Lisān al-Dīn (1983), al-Katība al-kāmina fĩ man laqīnāhu min shu'arā' al-mi'a althāmina, ed. by Iṇsān 'Abbās, Beirut: al-Dār al-'Arabiyya li-l-Kitāb.

Ibn al-Khațīb, Lisān al-Dīn (2016), Khațrat al-țayffí riḥlat al-shitā' wa-l-ṣayf (Visión de la amada ideal en una gira inverniza y estival), ed. and trans. by Fernando N. Velázquez Basanta, Almería: Fundación Ibn Tufayl de Estudios Árabes.

Ibn al-Khațīb, Lisān al-Dīn (1989), Nufäḍat al-jirāb fí 'ulālat al-ightirāb. Al-Juz' al-thālith, ed. by al-Sa'adiyya Fāghiya, Casablanca: Mațba'at al-Najāh al-Jadīda.

Ibn al-Khațīb, Lisān al-Dīn (1981), Rayḥānat al-kuttāb wa-nuj'at al-muntāb, ed. by Muḥammad 'Abd Allāh 'Inān, Cairo: Maktabat al-Khānjī.

Ibn Qāọī Shuhba, Taqī al-Dīn (1988), Ta’rīkh Ibn Qāọī Shuhba, ed. by 'Adnān Darwīsh, 4 vols., Damascus: Institut Français de Damas.

Al-Maqqarī, Aḥmad (1988), Naf̣̣ al-țīb fi ghuṣn al-Andalus al-rațīb, ed. by lḥsān 'Abbās, 8 vols., Beirut: Dār Șādir.

Al-Nasā’̄', 'Abd al-Raḥmān (1991), Sunan al-kubrā, ed. by 'Abd al-Ghaffār Sulaymān al-Bindārī and Sayyid Kasrawī Ḥasan, Beirut: Dār al-Kutub al-'Ilmiyya.

Al-Nasā'ī, 'Abd al-Raḥmān (2001), Sunan al-kubrā, ed. by Shua'yb al-Arna'ūṭ, Beirut: Mu'assasat al-Risāla.

Al-Sakhāwī (1992), al-Ḍaw' al-lāmi li-ahl al-qarn al-tāsi', ed. n.n., 12 vols., Beirut: Dār al-Jīl.

Al-Sakhāwī, Shams al-Dīn Muḥammad (1992), al-Dhayl al-tām 'alā Duwal al-islām li-l-Dhahabī, ed. by Ḥasan Ismāēil Marwa and Maḥmūd al-Arnā'ūṭ, 3 vols., Beirut - Kuwait: Dār Ibn al'Imād - Maktabat Dār al-'Arūba.

Al-Sakhāwī, Shams al-Dīn Muḥammad (1999), al-Jawāhir wa-l-durar fĩ tarjamat shaykh al-islām Ibn Ḥajar, ed. by Ibrāhīm Bājis al-Majīd, Beirut: Dār Ibn Ḥazm.

Al-Sakhāwī, Shams al-Dīn Muhammad (1995), Wajīz al-kalām fĩ al-dhayl 'alā Duwal al-islām, ed. by Bashshār 'Awwād Ma'rūf, 'Ișām Ḥarastānī and Aḥmad Khuṭaymī, 4 vols., Beirut: Mu’assasat al-Risāla. 
Sibṭ Ibn al-'Ajamī al-Ḥalabī (1996), Kunūz al-dhahab fí ta'rīkh Ḥalab, ed. by Shawqī Sha'th and Fāliḥ al-Bakkūr, Aleppo: Dār al-Qalam al-'Arabī.

Al-Suyūțī, Jalāl al-Dīn (1979), Bughyat al-wu'āt fi țabaqāt al-lughawiyyīn wa-l-nuhāt, ed. by Muḥammad Abū al-Faḍl Ibrāhīm, 2 vols., Beirut: Dār al-Fikr.

Al-'Ulaymī, Mujīr al-Dīn (1999), al-Uns al-jalīl bi-ta'rīkh al-Quds wa-l-Khalīl, ed. by Maḥmūd 'Awrah al-Ka'ābina, Amman - Hebron: Maktabat Dandis.

\section{Secondary bibliography}

Assmann, Jan / Czaplicka, John (1995), “Collective Memory and Cultural Identity”, New German Critique 65, 125-133.

Bauden, Fréderic / Franssen, Élisse (2019), In the Author's Hand: Holograph and Authorial Manuscripts in the Islamic Handwritten Tradition, Leiden - Boston: Brill.

Bauer, Thomas (2007), “The Dawādar's Hunting Party: A Mamluk Muzdawija Ṭardiyya, Probably by Shihāb al-Dīn Ibn Faḍll Allāh”, in: Arnoud Vrolijk and Jan P. Hogendijk, eds., O Ye Gentlemen: Arabic Studies on Science and Literary Culture in Honour of Remke Kruk, Leiden Boston: Brill, 291-312.

Behrens Abouseif, Doris (2019), The Book in Mamluk Egypt and Syria (1250-1517): Scribes, Libraries and Market, Leiden - Boston - Köln: Brill.

Brockelmann, Carl (2017), History of the Arabic Written Tradition, trans. by Joep Lameer, vol. 2, Leiden - Boston: Brill.

Calero Secall, María Isabel / Roser Nebot, Nicolás (2001), “El proceso de Ibn al-Jațīb. Apéndice: Epístola de al-Bunnāhī a Lisān al-dīn”, Al-Qanțara 22, 421-461.

Castro León, Víctor de (in press), "Ibn al-Khațīb and his Mamluk reception”, in: Proceedings of the Fifth Conference of the School of Mamluk Studies, Leiden - Boston: Brill.

Confino, Alon (1997), "Collective Memory and Cultural History: Problems of Method", The American Historical Review 102, 1386-1403.

Damaj, Ahmad (2004), “Ibn Fatḥ al-Muntašāqarī, Abū l-Ḥaŷŷaŷ”, in: Jorge Lirola Delgado and José Miguel Puerta Vílchez, eds., Biblioteca de al-Andalus 3: De Ibn al-Dabbāg a Ibn Kurz, Almería: Fundación Ibn Tufayl de Estudios Árabes, 160-162.

Espinar Moreno, Manuel (2019), “Las aguas de la acequia de Mogayra del río de Alcázar en el Marquesado del Cenete (siglos XIII-XV)", in: Manuel Espinar Moreno, Las aguas de Guadix y el Cenete, Granada: LibrosEPCCM, 65-98.

Frenkel, Yehoshua (2018), “Mamluk Historiography Revisited: Narratological Perspective in Damascene Chronicles”, in: Stephan Conermann, ed., Mamluk Historiography Revisited Narratological Perspectives, Göttingen: V\&R Unipress and Bonn University Press, 27-50.

Ibn Tāwīt al-Ṭanjī, Muḥammad (1979), “Kitāb al-Iḥāța li-Ibn al-Khațīb”, Al-Manāhil 6, 326-371.

Lirola Delgado, Jorge / López y López, Ángel Custodio (2004), “Ibn al-Ḥāŷŷy al-Numayrī, Abū Isḥāq", in: Jorge Lirola Delgado and José Miguel Puerta Vílchez, eds., Biblioteca de al-Andalus 3: De Ibn al-Dabbāg a Ibn Kurz, Almería: Fundación Ibn Tufayl de Estudios Árabes, 341-350.

Lirola Delgado, Jorge, et al. (2004), “Ibn al-Jațīb al-Salmānī, Lisān al-Dīn”, in: Jorge Lirola Delgado and José Miguel Puerta Vílchez, eds., Biblioteca de al-Andalus 3: De lbn al-Dabbāg a Ibn Kurz, Almería: Fundación Ibn Tufayl de Estudios Árabes, 643-698. 
Lirola Delgado, Jorge / Ferrando, Ignacio (2009), “Ibn Ŷābir al-Hawwārī, Abū 'Abd Allāh”, in: Jorge Lirola Delgado, ed., Biblioteca de al-Andalus 6: De Ibn al-Ŷabbāb a Nubḍat al-'așr, Almería: Fundación Ibn Tufayl de Estudios Árabes, 18-25.

Little, Donald (1995), “Mujīr al-Dīn al-'Ulaymī's Vision of Jerusalem in the Ninth/Fifteenth Century", Journal of the American Oriental Society 115, 237-247.

Manzano Rodríguez, Miguel Ángel, “Ibn Jaldūn, 'Abd al-Raḥmān”, in: Jorge Lirola Delgado and José Miguel Puerta Vílchez, eds., Biblioteca de al-Andalus 3: De Ibn al-Dabbāg a Ibn Kurz, Almería: Fundación Ibn Tufayl de Estudios Árabes, 578-597.

Megill, Allan (2007), Historical Knowledge, Historical Error: A Contemporary Guide to Practice, Chicago - London: The University of Chicago Press.

Miura, Toru (2015), Dynamism in the Urban Society of Damascus: The Șālihiyya Quarter from the Twelfth to the Twentieth Centuries, Leiden - Boston - Köln: Brill.

Molina, Luis (2015), “Sobre el autor del Dikr bilād al-Andalus”, Al-Qanțara 36, 259-272.

Navarro i Ortiz, Eduardo / Lirola Delgado, Jorge (2012), "al-Ru'aynī, Abū Ŷa'far," in: Jorge Lirola Delgado, ed., Biblioteca de al-Andalus 7: De al-Qabrīrī a Zumurrud, Almería: Fundación Ibn Tufayl de Estudios Árabes, 179-184.

Peláez Rovira, Antonio (2006), “Ibn Marzūq, Abū 'Abd Allāh”, in: Jorge Lirola Delgado, ed., Biblioteca de al-Andalus 4: De Ibn al-Labbāna a Ibn al-Ruyūlī, Almería: Fundación Ibn Tufayl de Estudios Árabes, 124-138.

Puente, Cristina de la (2012), “al-Balafĩqī, Abū l-Barakāt”, in: Jorge Lirola Delgado and José Miguel Puerta Vílchez, eds., Biblioteca de al-Andalus 1: De al-Abbādīya a Ibn Abyaḍ, Almería: Fundación Ibn Tufayl de Estudios Árabes, 160-164.

Reynolds, Dwight F., ed. (2001), Interpreting the Self: Autobiography in the Arabic Literary Tradition, Berkeley - Los Angeles - London: University of California Press.

Richardson, Kristina (2016), “The Evolving Biographical Legacy of Two late Mamluk Hanbali Judges", in: Stephan Conermann, ed., History and Society during the Mamluk Period (1250-1517). Studies of the Annemarie Schimmel Institute for Advanced Study II, Bonn: Bonn University Press, 29-50.

Rodríguez Figueroa, Antonio (2012), “Al- 'Azafí, Abū l-Qāsim Muḥammad”, in: Jorge Lirola Delgado and José Miguel Puerta Vílchez, eds., Biblioteca de al-Andalus 1: De al-'Abbādīya a Ibn Abyaḍ, Almería: Fundación Ibn Tufayl de Estudios Árabes, 133-134.

Rubiera Mata, María Jesús / Kalaitzidou, Mariana (2009), “Ibn al-Ŷayyāb, Abū l-Ḥasan”, in: Jorge Lirola Delgado, ed., Biblioteca de al-Andalus 6: De Ibn al-Ŷabbāb a Nubḍat al-'așr, Almería: Fundación Ibn Tufayl de Estudios Árabes, 129-133.

Velázquez Basanta, Fernando Nicolás (2009a), “Ibn Ŷuzayy al-Kalbī, Abū 'Abd Allāh”, in: Jorge Lirola Delgado, ed., Biblioteca de al-Andalus 6: De Ibn al-Ŷabbāb a Nubḍat al-'așr, Almería: Fundación Ibn Tufayl de Estudios Árabes, 180-195.

Velázquez Basanta, Fernando Nicolás (2009b), “Ibn Ŷuzayy al-Kalbī, Abū Muḥammad”, in: Jorge Lirola Delgado, ed., Biblioteca de al-Andalus 6: De Ibn al-Ŷabbāb a Nubḍat al-'așr, Almería: Fundación Ibn Tufayl de Estudios Árabes, 203-214.

Wādi' al-Thabītī, 'Alī Jābir (1418/1997-8), Burhān al-Dīn Ibrāhīm b. Muhammad al-Ḥalabī, Ph.D. Thesis, Jāmi'at Umm al-Qurā'.

Washnān, Tayyibī (2019), “Al-Imām al-Adīb al-Raḥḥāla Muḥammad b. Muḥammad b. 'Alī lbn Ḥizb Allāh al-Wādī Āshī (712-788)”, Al-Zuqāq 3, 129-164.

Ženka, Josef (2018), "A Manuscript of the Last Sultan of al-Andalus and the Fate of the Royal Library of the Nasrid Sultans at the Alhambra", Journal of Islamic Manuscripts 9, 341-376. 